
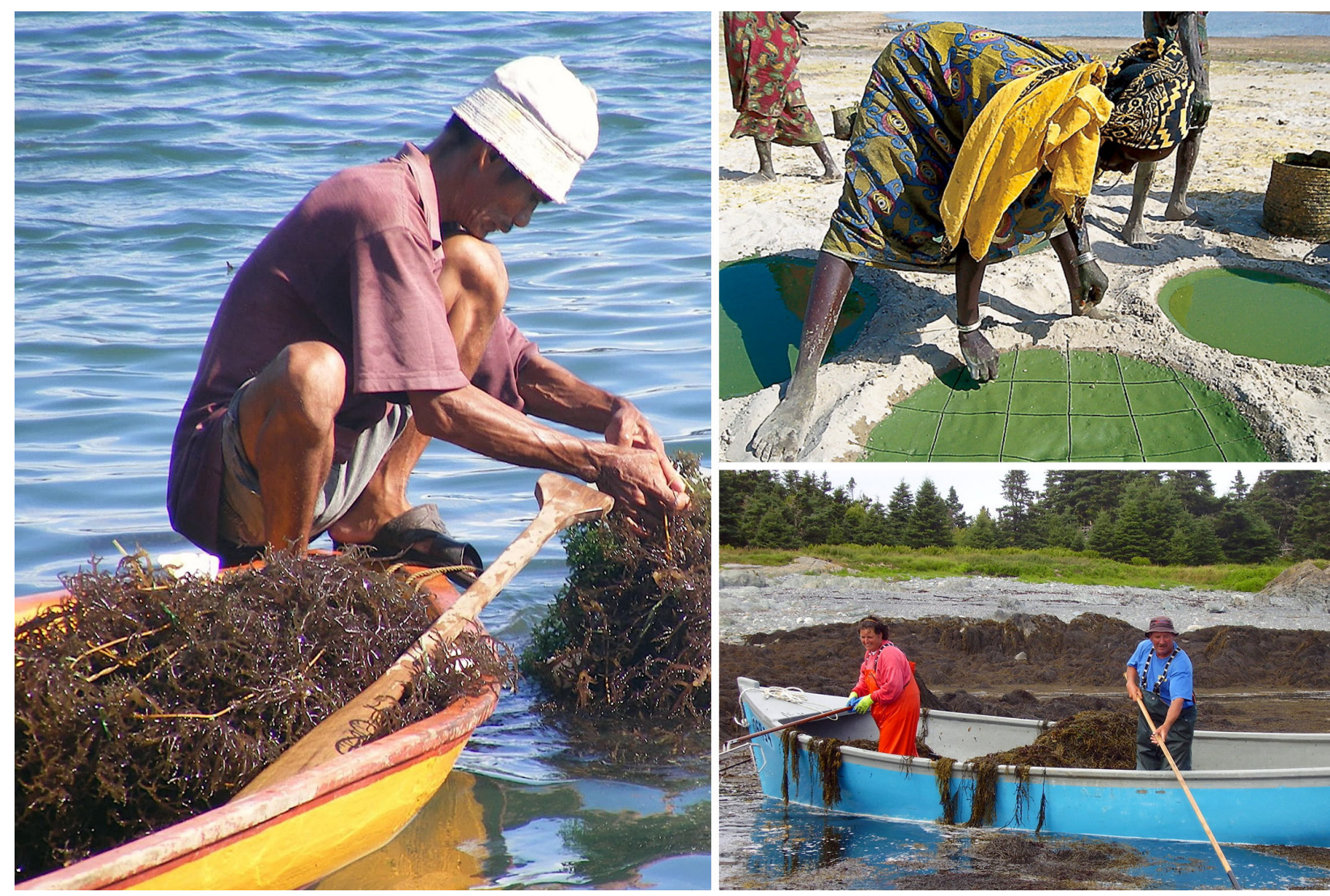
Cover photographs: Cultivation of Kappaphycus alvarezii in the Philippines (left; @A. Hurtado). Production of spirulina in Chad (upper right; OFAO/M. Marzot). Wild collection of Ascophyllum nodosum in Canada (lower right; (CL. Cornish). 


\section{SEAWEEDS AND MICROALGAE: AN OVERVIEW FOR UNLOCKING THEIR POTENTIAL IN GLOBAL AQUACULTURE DEVELOPMENT}

by

Junning Cai (lead); Alessandro Lovatelli (co-lead); Esther Garrido Gamarro; James Geehan; Daniela Lucente; Graham Mair; Weimin Miao; Melba Reantaso; Rodrigo Roubach; Xinhua Yuan FAO Fisheries and Aquaculture Division - Natural Resources and Sustainable Production

José Aguilar-Manjarrez

FAO Regional Office for Latin America and the Caribbean

Lynn Cornish

Acadian Seaplants Limited (Canada)

Lionel Dabbadie

FAO Subregional Office for the Gulf Cooperation Council States and Yemen

\section{Anne Desrochers}

FAO Subregional Office for the Caribbean

Simon Diffey; Mele Tauati

FAO Subregional Office for the Pacific Islands

Anicia Hurtado

Integrated Services for the Development of Aquaculture and Fisheries (ISDA) Inc. (Philippines)

Philippe Potin

The French National Centre for Scientific Research (CNRS)

and

Cyrille Przybyla

French National Institute for Ocean Science (Ifremer) 
Required citation:

Cai, J., Lovatelli, A., Aguilar-Manjarrez, J., Cornish, L., Dabbadie, L., Desrochers, A., Diffey, S., Garrido Gamarro, E., Geehan, J., Hurtado, A., Lucente, D., Mair, G., Miao, W., Potin, P., Przybyla, C., Reantaso, M., Roubach, R., Tauati, M. \& Yuan, X. 2021. Seaweeds and microalgae: an overview for unlocking their potential in global aquaculture development. FAO Fisheries and Aquaculture Circular No. 1229. Rome, FAO. https://doi.org/10.4060/cb5670en

The designations employed and the presentation of material in this information product do not imply the expression of any opinion whatsoever on the part of the Food and Agriculture Organization of the United Nations (FAO) concerning the legal or development status of any country, territory, city or area or of its authorities, or concerning the delimitation of its frontiers or boundaries. The mention of specific companies or products of manufacturers, whether or not these have been patented, does not imply that these have been endorsed or recommended by FAO in preference to others of a similar nature that are not mentioned.

The views expressed in this information product are those of the author(s) and do not necessarily reflect the views or policies of FAO

ISBN 978-92-5-134710-2

(C) FAO, 2021

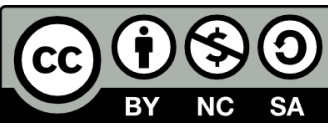

Some rights reserved. This work is made available under the Creative Commons Attribution-NonCommercial-ShareAlike 3.0 IGO licence (CC BY-NC-SA 3.0 IGO; https://creativecommons.org/licenses/by-nc-sa/3.0/igo/legalcode).

Under the terms of this licence, this work may be copied, redistributed and adapted for non-commercial purposes, provided that the work is appropriately cited. In any use of this work, there should be no suggestion that FAO endorses any specific organization, products or services. The use of the FAO logo is not permitted. If the work is adapted, then it must be licensed under the same or equivalent Creative Commons licence. If a translation of this work is created, it must include the following disclaimer along with the required citation: "This translation was not created by the Food and Agriculture Organization of the United Nations (FAO). FAO is not responsible for the content or accuracy of this translation. The original [Language] edition shall be the authoritative edition."

Disputes arising under the licence that cannot be settled amicably will be resolved by mediation and arbitration as described in Article 8 of the licence except as otherwise provided herein. The applicable mediation rules will be the mediation rules of the World Intellectual Property Organization http://www.wipo.int/amc/en/mediation/rules and any arbitration will be conducted in accordance with the Arbitration Rules of the United Nations Commission on International Trade Law (UNCITRAL).

Third-party materials. Users wishing to reuse material from this work that is attributed to a third party, such as tables, figures or images, are responsible for determining whether permission is needed for that reuse and for obtaining permission from the copyright holder. The risk of claims resulting from infringement of any third-party-owned component in the work rests solely with the user.

Sales, rights and licensing. FAO information products are available on the FAO website (www.fao.org/publications) and can be purchased through publications-sales@fao.org. Requests for commercial use should be submitted via: www.fao.org/contact-us/licence-request. Queries regarding rights and licensing should be submitted to: copyright@fao.org. 


\section{PREPARATION OF THIS DOCUMENT}

This document is a discussion paper that provides a balanced overview of the algae sector with a focus on its contribution and potential in global aquaculture development. The overview is intended to facilitate discussion on algae-related issues at the Eleventh Session of the SubCommittee on Aquaculture, the FAO Committee on Fisheries (COFI), which is expected to be held in Mérida, Yucatán, Mexico, from 15 to 18 November 2021. The paper also lays a foundation for more comprehensive, in-depth assessment in the future.

The paper was based on inputs from a number of FAO staff and external experts. They are acknowledged on the title page in the alphabetic order of their surnames, except for the two lead authors. PingSun Leung is acknowledged for his valuable review of the document. Maria Kalentsits is acknowledged for her assistance in literature search. Maria Giannini and Marianne Guyonnet are acknowledged for their assistance in editing and formatting. José Luis Castilla Civit is acknowledged for his assistance in cover design. 


\section{ABSTRACT}

Algae, including seaweeds and microalgae, contribute nearly 30 percent of world aquaculture production (measured in wet weight), primarily from seaweeds. Seaweeds and microalgae generate socio-economic benefits to tens of thousands of households, primarily in coastal communities, including numerous women empowered by seaweed cultivation. Various human health contributions, environmental benefits and ecosystem services of seaweeds and microalgae have drawn increasing attention to untapped potential of seaweed and microalgae cultivation. Highly imbalanced production and consumption across geographic regions implies a great potential in the development of seaweed and microalgae cultivation. Yet joint efforts of governments, the industry, the scientific community, international organizations, civil societies, and other stakeholders or experts are needed to realize the potential. This document examines the status and trends of global algae production with a focus on algae cultivation, recognizes the algae sector's existing and potential contributions and benefits, highlights a variety of constraints and challenges over the sector's sustainable development, and discusses lessons learned and way forward to unlock full potential in algae cultivation and FAO's roles in the process. From a balanced perspective that recognizes not only the potential of algae but also constraints and challenges upon the realization of the potential, information and knowledge provided by this document can facilitate evidence-based policymaking and sector management in algae development at the global, regional and national levels. 


\section{CONTENTS}

Preparation of this document $\quad$ iii

Abstract iv

Abbreviations and acronyms $\quad$ vii

1. INTRODUCTION 1

2. STATUS AND TRENDS OF GLOBAL ALGAE PRODUCTION 2

2.1 Brown seaweeds $\quad 4$

2.2 Red seaweeds 5

2.3 Green seaweeds (excluding green microalgae) 7

2.4 Stylized facts of seaweed cultivation 8

$\begin{array}{ll}2.5 \text { Microalgae } & 10\end{array}$

3. SOCIAL, ECONOMIC AND ENVIRONMENTAL CONTRIBUTION OF ALGAE 11

3.1 Contribution to food, nutrition and human health 11

3.2 Contribution to income, livelihood and social cohesion $\quad 12$

3.3 Environmental benefits and ecosystem services 13

$\begin{array}{ll}3.4 \text { Contribution to aquaculture } & 13\end{array}$

4. ISSUES, CONSTRAINTS AND CHALLENGES 14

4.1 Limited or uncertain demand for seaweeds 15

4.2 Limited or reduced availability of suitable farm sites nearshore $\quad 15$

$\begin{array}{ll}4.3 \text { Shortage of labour } & 16\end{array}$

4.4 Constraints over integrated farming systems 16

$\begin{array}{ll}\text { 4.5 Low or declined seedling quality } & 17\end{array}$

4.6 Miscellaneous issues or constraints over seaweed cultivation and value chains $\quad 18$

4.7 Environmental/ecosystem impacts or risks 18

4.8 Issues and constraints over microalgae cultivation 18

$\begin{array}{ll}4.9 \text { Algae blooms } & 19\end{array}$

5. LESSONS LEARNED AND WAY FORWARD 20

5.1 Governance as foundation 20

5.2 Market demand as driving force $\quad 21$

5.3 Innovation as game changer $\quad 22$

5.4 Public support as enabling environment 23

5.5 FAO's roles 24

$\begin{array}{lr}\text { REFERENCES } & 28\end{array}$ 



\section{ABBREVIATIONS AND ACRONYMS}

ANSES

ASFIS

DHA

EFSA

FAM

FAO

IIMSAM

IMTA

IUCN

JECFA

NDA

nei

NOAA

$\mathrm{PMP} / \mathrm{AB}$

SDG

UCTV

UN

UNGA

USD

WAPI
French Agency for Food, Environmental and Occupational Health \& Safety Aquatic Sciences and Fisheries Information System docosahexaenoic acid European Food Safety Authority freshwater aquatic macrophyte Food and Agriculture Organization of the United Nations The Autonomous Intergovernmental Institution for the Use of Micro-algae Spirulina Against Malnutrition integrated multitrophic aquaculture International Union for Conservation of Nature Joint FAO/WHO Expert Committee on Food Additives The Panel on Nutrition, Novel Foods and Food Allergens not elsewhere included National Oceanic and Atmospheric Administration Progressive Management Pathway for Improving Aquaculture Biosecurity Sustainable Development Goal University of California Television United Nations The United Nations General Assembly United States Dollar World Aquaculture Performance Indicators 



\section{INTRODUCTION}

Algae referred to in this document include seaweeds (i.e. marine macroalgae) and microalgae, which are photosynthetic aquatic organisms. Algae play a vital role in the aquatic ecosystem by forming the energy base of the food web for all aquatic organisms; they provide various environmental benefits and ecosystem services, such as eutrophication mitigation, carbon capture or sequestration, ocean acidification amelioration, habitat provision and shoreline protection, among others.

Consideration of other photosynthetic aquatic plants, such as seagrass, halophytic plants and freshwater aquatic macrophytes (FAMs), is beyond the scope of this document. While the cultivation of FAMs has become a substantial aquaculture sub-sector, particularly in Asia, there is a general lack of systematic information and knowledge regarding the sector (FAO, forthcoming).

Algae, particularly seaweeds, are an important component of global aquaculture. In 2019, algae cultivation, measured in wet weight, ${ }^{1}$ contributed nearly 30 percent of the 120 million tonnes of world aquaculture production, ${ }^{2}$ and red seaweeds (Rhodophyta) and brown seaweeds (Phaeophyceae) were, respectively, the second- and third-largest species groups in global aquaculture, only smaller than "Carps, barbels and other cyprinids" (FAO, 2021a).

Being mostly low-value commodities, seaweeds accounted for 5.4 percent of the USD 275 billion of world aquaculture production value in 2019. Still, the 5.4 percent value share remained higher than that of "Tilapias and other cichlids" or "Catfishes", and was only lower than that of four species groups: (i.e. "Carps, barbels and other cyprinids"; "Marine shrimps and prawns"; "Salmons, trouts, smelts"; and "Crayfishes") (FAO, 2021b).

Seaweeds, however, are not well known in many parts of the world, as their production is mostly concentrated in Eastern and South-eastern Asia. ${ }^{3}$ On the demand side, while in Eastern Asia seaweeds have become widely and frequently consumed human foods, in other parts of the world seaweeds are largely niche or novel foods, mostly eaten in some coastal communities as traditional foods or by a relatively small number of consumers for various purposes, which could be dietary (e.g. as exotic foods from Oriental cuisine), nutritional (e.g. supplementing micronutrients), environmental (e.g. as products with a low environmental footprint) and/or social (e.g. plant-based diets for animal welfare).

Seaweeds have multiple other uses in food and non-food industries, such as food additives, animal feeds, pharmaceuticals, nutraceuticals, cosmetics, textiles, biofertilizer/biostimulants, bio-packaging, and biofuel, among others (McHugh, 2003; FAO, 2018). However, knowledge of their contribution to these products is generally confined to seaweed-related industries and the scientific community.

With their various social, environmental and economic contribution and benefits (Bjerregaard et al., 2016), the potential contributions of seaweeds to multiple Sustainable Development Goals (SDGs) (e.g. SDG 1, SDG 2, SDG 3, SDG 8, SGD 10, SDG 12, SDG 13 and SDG 14) have been recognized, for example, in a "Seaweed Manifesto". ${ }^{4}$ There is a growing interest in seaweeds from several sectors, with a particular focus on their potential as a source of nutritious food to feed the growing human population and for the ecosystem services they provide, particularly in reducing greenhouse gases (Parodi et

\footnotetext{
${ }^{1}$ Unless specified otherwise, in this document production tonnage is measured in wet weight.

${ }^{2}$ Unless noted otherwise, aquaculture and fisheries production statistics presented in this document are from FAO. 2021c. Fishery and Aquaculture Statistics. Global production by production source 1950-2019 (FishStatJ). www.fao.org/fishery/statistics/software/fishstatj/en

${ }^{3}$ Unless noted otherwise, country grouping in this document follows the United Nations M49 standard.

${ }^{4}$ https://unglobalcompact.org/library/5743
} 
al., 2018; Duarte et al., 2020). The existence of vast marine areas suitable for seaweed farming makes champions of seaweeds envision a forthcoming "Seaweed Revolution". 5

There is a growing consensus that wild resources will not be able to supply enough seaweeds to satisfy future demand despite the robust management strategies in many areas (Steen et al., 2016; Monagail et al., 2017; Lauzon-Guay et al., 2021). Aquaculture is the primary means to ensure safety and traceability and to help unlock the great potential of seaweeds. However, the sustainable development of seaweed cultivation faces various issues, constraints and challenges that entail joint efforts of policy-makers, stakeholders and experts to address or overcome.

Microalgae cultivation appears much smaller than seaweeds - commercial microalgae cultivation recorded in FAO statistics contributed less than 0.2 percent of global algae cultivation tonnage in 2019 . Microalgae cultivation, however, plays crucial roles in the farming of aquatic animal species (e.g. as direct hatchery/nursery feeds or essential part of primary nutrient cycles operating within a pond culture system for rearing finfish, shrimp or other animal species), although such intermediate products or services provided by microalgae are usually not recorded in official statistics. Similar to seaweeds, microalgae also have great potential in various food and non-food applications (Khan, Shin and Kim, 2018); many of which nevertheless entail significant joint efforts to become fully commercialized.

Sustainable algae sector development entails the recognition of not only its potential contributions and benefits but also constraints and challenges upon the realization of the potential. This paper provides a balanced overview of the algae sector, which includes (i) examination of the status and trends of global algae production (section 2); (ii) assessment of the sector's social, economic and environmental contributions (section 3); (iii) highlight of issues, constraints and challenges in the algae sector development (section 4); and (iv) discussion of lessons learned and way forward to unlock full potential in algae cultivation and FAO's roles in the process (section 5).

\section{STATUS AND TRENDS OF GLOBAL ALGAE PRODUCTION}

World seaweed production is primarily supported by aquaculture. In 1969, the 2.2 million tonnes of world seaweed production was evenly divided between wild collection and cultivation. A half century later, however, while wild collection remained at 1.1 million tonnes in 2019, cultivation increased to 34.7 million tonnes, which accounted for 97 percent of world seaweed production in 2019 (Cai et al., 2021).

There is a strong regional imbalance in seaweed production. In 2019, seaweed production in Asia (99.1 percent from cultivation) contributed 97.4 percent of world production, and seven of the top ten seaweed producing countries were from Eastern or South-eastern Asia (Table 1).

The Americas and Europe contributed, respectively, 1.4 percent and 0.8 percent of world seaweed production in 2019. Seaweed production in these two regions was primarily fulfilled by wild collection, and cultivation only accounted for 4.7 percent and 3.9 percent of total seaweed production, respectively (Table 1).

In contrast, cultivation was the main source of seaweed production in Africa ( 81.3 percent) and Oceania ( 85.3 percent), although their contribution to world seaweed production was only 0.4 percent and 0.05 percent, respectively (Table 1 ).

\footnotetext{
${ }^{5} \mathrm{https}: / /$ seaweedrevolution.live.ft.com
} 
Table 1: Global seaweed production, 2019

\begin{tabular}{|c|c|c|c|c|}
\hline \multirow[b]{2}{*}{ Country/area } & \multicolumn{2}{|c|}{$\begin{array}{l}\text { Total seaweed production } \\
\text { (farmed and wild) }\end{array}$} & \multicolumn{2}{|c|}{ Seaweed cultivation } \\
\hline & $\begin{array}{c}\text { Tonnes } \\
\text { (wet weight) }\end{array}$ & $\begin{array}{l}\text { Share of } \\
\text { world } \\
\text { production } \\
(\%)\end{array}$ & $\begin{array}{c}\text { Tonnes } \\
\text { (wet weight) }\end{array}$ & $\begin{array}{l}\text { Share in } \\
\text { farmed and } \\
\text { wild } \\
\text { production } \\
(\%)\end{array}$ \\
\hline World & 35762504 & 100.00 & 34679134 & 96.97 \\
\hline Asia & 34826750 & 97.38 & 34513223 & 99.10 \\
\hline 1. China & 20296592 & 56.75 & 20122142 & 99.14 \\
\hline 2. Indonesia & 9962900 & 27.86 & 9918400 & 99.55 \\
\hline 3. Republic of Korea & 1821475 & 5.09 & 1812765 & 99.52 \\
\hline 4. Philippines & 1500326 & 4.20 & 1499961 & 99.98 \\
\hline 5. Democratic People's Republic of Korea & 603000 & 1.69 & 603000 & 100.00 \\
\hline 7. Japan & 412300 & 1.15 & 345500 & 83.80 \\
\hline 8. Malaysia & 188110 & 0.53 & 188110 & 100.00 \\
\hline Rest of Asia ( 7 countries/territories) & 42047 & 0.12 & 23344 & 55.52 \\
\hline Americas & 487241 & 1.36 & 22856 & 4.69 \\
\hline 6. Chile & 426605 & 1.19 & 21679 & 5.08 \\
\hline Peru & 36348 & 0.10 & - & - \\
\hline Canada & 12655 & 0.04 & - & - \\
\hline Mexico & 7336 & 0.02 & 10 & 0.14 \\
\hline United States of America & 3394 & 0.01 & 263 & 7.75 \\
\hline Rest of the Americas (6 countries) & 904 & 0.00 & 904 & 100.00 \\
\hline Europe & 287033 & 0.80 & 11125 & 3.88 \\
\hline 9. Norway & 163197 & 0.46 & 117 & 0.07 \\
\hline France & 51476 & 0.14 & 176 & 0.34 \\
\hline Ireland & 29542 & 0.08 & 42 & 0.14 \\
\hline Russian Federation & 19544 & 0.05 & 10573 & 54.10 \\
\hline Iceland & 17533 & 0.05 & - & - \\
\hline Rest of Europe (5 countries) & 5741 & 0.02 & 217 & 3.78 \\
\hline Africa & 144909 & 0.41 & 117791 & 81.29 \\
\hline 10. United Republic of Tanzania & 106069 & 0.30 & 106069 & 100.00 \\
\hline Zanzibar & 104620 & 0.29 & 104620 & 100.00 \\
\hline Tanzania (mainland) & 1449 & 0.00 & 1449 & 100.00 \\
\hline Morocco & 17591 & 0.05 & 273 & 1.55 \\
\hline South Africa & 11155 & 0.03 & 2155 & 19.32 \\
\hline Madagascar & 9665 & 0.03 & 8865 & 91.72 \\
\hline Rest of Africa ( 2 countries) & 430 & 0.00 & 430 & 100.00 \\
\hline Oceania & 16572 & 0.05 & 14140 & 85.32 \\
\hline Solomon Islands & 5600 & 0.02 & 5600 & 100.00 \\
\hline Papua New Guinea & 4300 & 0.01 & 4300 & 100.00 \\
\hline Kiribati & 3650 & 0.01 & 3650 & 100.00 \\
\hline Australia & 1923 & 0.01 & - & \\
\hline Rest of Oceania (3 countries) & 1099 & 0.00 & 590 & 53.66 \\
\hline
\end{tabular}

Source: FAO. 2021c. Fishery and Aquaculture Statistics. Global production by production source 1950-2019 (FishStatJ). Notes: The top 10 seaweed producing countries are indexed. “-” indicates zero or no data. 
Seaweeds are broadly classified into three taxonomic groups: brown seaweeds (around 2000 species under Phaeophyceae), red seaweeds (over 7200 species under Rhodophyta) and green seaweeds (more than 1800 macroalgae species under Chlorophyta). ${ }^{6,7}$

Seaweed cultivation is concentrated on a relatively small number of species. FAO statistics record only 27 different ASFIS ${ }^{8}$ (Aquatic Sciences and Fisheries Information System) seaweed species items cultivated in 2019, a fraction (6.1 percent) of the total 443 ASFIS species items in global aquaculture, even though seaweeds accounted for nearly 30 percent of world aquaculture production in terms of wet weight (FAO, 2021d).

It should be noted that FAO statistics may not record or distinctly reveal some aquaculture species (including seaweed species) because of underreporting, confidentiality or other reasons. Despite such data imperfections, it can be concluded with high confidence that seaweed cultivation tends to have relatively low species diversity in contrast to the aquaculture of animal species.

\subsection{Brown seaweeds}

World cultivation of brown seaweeds increased from 13000 tonnes in 1950 to 16.4 million tonnes in 2019; the average 10.9 percent annual growth during 1950-2019 was higher than the 7.9 percent growth in world aquaculture of all species.

In 2019, brown seaweeds accounted for 47.3 percent of world seaweed cultivation in terms of tonnage and 52 percent in terms of value. Brown seaweed cultivation has concentrated on two cold-water genera: Laminaria/Saccharina (also known as kelp) and Undaria (also known as wakame).

In 2019, the 12.3 million tonnes of Laminaria/Saccharina (primarily Laminaria [Saccharina] japonica ${ }^{9}$ ) cultivation (35.4 percent of all seaweeds) was supplied by seven countries, comprising four countries in Eastern Asia and three countries in Europe (Table 2). The 2.6 million tonnes of Undaria (primarily $U$. pinnatifida) cultivation ( 7.4 percent of all seaweeds) was supplied by four countries, comprising three countries in Eastern Asia and one country in Europe (Table 3).

Table 2: Laminaria/Saccharina cultivation production, 2019

\begin{tabular}{l|r|r}
\hline \multirow{2}{*}{ Country/area } & \multicolumn{2}{|c}{ Laminaria/Saccharina cultivation } \\
\cline { 2 - 3 } & Tonnes (wet weight) & \multicolumn{1}{c}{ Share of world (\%) } \\
\cline { 2 - 3 } World & $\mathbf{1 2 ~ 2 7 3 7 4 8}$ & $\mathbf{1 0 0 . 0 0}$ \\
\hline 1. China & 10978362 & 89.45 \\
\hline 2. Republic of Korea & 662557 & 5.40 \\
\hline 3. Democratic People's Republic of Korea & 600000 & 4.89 \\
\hline 4. Japan & 32600 & 0.27 \\
\hline 5. Faroe Islands & 156 & 0.00 \\
\hline 6. Norway & 73 & 0.00 \\
\hline 7. Spain & 0.14 & 0.00 \\
\hline
\end{tabular}

Source: FAO. 2021c. Fishery and Aquaculture Statistics. Global production by production source 1950-2019 (FishStatJ).

\footnotetext{
${ }^{6}$ www.seaweed.ie

${ }^{7}$ www.americanscientist.org/article/the-science-of-seaweeds

${ }^{8}$ ASFIS - Aquatic Sciences and Fisheries Information System - species items in FAO statistics could refer to either individual species, hybrids or groups of related species, such as families (when identification to species is impossible). www.fao.org/fishery/collection/asfis/en

${ }^{9}$ In order to avoid confusion, the document follows taxonomic nomenclatures used in FAO statistics even when there are more updated taxonomic names; e.g. Laminaria japonica is used instead of Saccharina japonica; Porphyra is used instead of Pyropia or Neoporphyra.
} 
Table 3: Undaria cultivation production, 2019

\begin{tabular}{l|r|r}
\hline \multirow{2}{*}{ Country/area } & \multicolumn{2}{|c}{ Undaria cultivation } \\
\cline { 2 - 3 } & Tonnes (wet weight) & \multicolumn{1}{c}{ Share of world (\%) } \\
\hline World & $\mathbf{2 5 6 3 5 8 2}$ & $\mathbf{1 0 0 . 0 0}$ \\
\hline 1. China & 2023930 & 78.95 \\
\hline 2. Republic of Korea & 494947 & 19.31 \\
\hline 3. Japan & 44600 & 1.74 \\
\hline 4. France & 105 & 0.00 \\
\hline
\end{tabular}

Source: FAO. 2021c. Fishery and Aquaculture Statistics. Global production by production source 1950-2019 (FishStatJ).

Other minor brown seaweed species under cultivation include:

- 1.25 million tonnes of unidentified brown seaweeds cultivated in four countries: China (1.24 million tonnes), the Russian Federation (11 000 tonnes), the United States of America (241 tonnes) and Mexico (10 tonnes);

- 304000 tonnes of Sargassum (primarily S. fusiforme) cultivated in two Eastern Asian countries: China (270 000 tonnes) and the Republic of Korea (34 000 tonnes);

- 105 tonnes of Alaria esculenta (also known as bladderlocks, dabberlocks or winged kelp) cultivated in three Northern European countries: Norway (44 tonnes), Ireland (42 tonnes) and the Faroe Islands (19 tonnes);

- 90 tonnes of Cladosiphon okamuranus (also known as mozuku) cultivated in Tonga - the cultivation of C. okamuranus in Okinawa, Japan (Sato et al., 2021), is not distinctly recorded in FAO statistics but may be embedded under "Seaweeds nei"; and

- 2 tonnes of Macrocystis pyrifera (also known as giant kelp) cultivated in Chile.

Cultivated brown seaweeds are mostly used as human foods (e.g. kombu soup and wakame salads) as well as abalone feed. ${ }^{10}$ They are also used as raw materials to produce (i) alginate (a hydrocolloid for various food and non-food uses); (ii) animal feeds; (iii) biofertilizer or biostimulants; (iv) pharmaceutical or nutraceutical products; and (v) compostable bio-packaging; among others (McHugh, 2003; FAO, 2018).

\subsection{Red seaweeds}

World cultivation of red seaweeds increased from 21000 tonnes in 1950 to 18.3 million tonnes in 2019; the 10.3 percent annual growth was slightly lower than that of brown seaweeds, yet still much higher than the 7.9 percent growth for world aquaculture of all species.

In 2019, red seaweeds accounted for 52.6 percent of world seaweed cultivation in terms of tonnage and 47.6 percent in terms of value. Red seaweed cultivation is concentrated on two warm-water genera (Kappaphycus/Eucheuma and Gracilaria) and one cold-water genus (Porphyra, also known as nori).

The 11.6 million tonnes of Kappaphycus/Eucheuma cultivation in 2019 (33.6 percent of all seaweeds) was provided by 23 countries or territories, comprising nine countries in Asia, four countries or territories in Eastern Africa, four Pacific Island states, and six countries in Latin America and the Caribbean (Table 4).

\footnotetext{
${ }^{10}$ In China, high-quality kelp (Laminaria japonica) is usually used for human consumption, whereas low-grade kelp (including scraps) is used as abalone feed (FAO, 2020a).
} 
Table 4: Kappaphycus/Eucheuma cultivation production, 2019

\begin{tabular}{|c|c|c|}
\hline \multirow[b]{2}{*}{ Country/area } & \multicolumn{2}{|c|}{ Kappaphycus/Eucheuma cultivation } \\
\hline & $\begin{array}{c}\text { Tonnes } \\
\text { (wet weight) }\end{array}$ & Share of world (\%) \\
\hline World & 11622213 & 100.00 \\
\hline Asia & 11491956 & 98.88 \\
\hline Indonesia & 9795400 & 84.28 \\
\hline Philippines & 1498788 & 12.90 \\
\hline Malaysia & 188110 & 1.62 \\
\hline China & 4200 & 0.04 \\
\hline Cambodia & 2000 & 0.02 \\
\hline Viet Nam & 1700 & 0.01 \\
\hline Timor-Leste & 1500 & 0.01 \\
\hline Sri Lanka & 247 & 0.00 \\
\hline Myanmar & 11 & 0.00 \\
\hline Africa & 115334 & 0.99 \\
\hline United Republic of Tanzania & 106069 & 0.91 \\
\hline Zanzibar & 104620 & 0.90 \\
\hline Tanzania (mainland) & 1449 & 0.01 \\
\hline Madagascar & 8865 & 0.08 \\
\hline Kenya & 400 & 0.00 \\
\hline Oceania & 14050 & 0.12 \\
\hline Solomon Islands & 5600 & 0.05 \\
\hline Papua New Guinea & 4300 & 0.04 \\
\hline Kiribati & 3650 & 0.03 \\
\hline Fiji & 500 & 0.00 \\
\hline Latin America and the Caribbean & 874 & 0.01 \\
\hline Brazil & 700 & 0.01 \\
\hline Saint Lucia & 103 & 0.00 \\
\hline Ecuador & 45 & 0.00 \\
\hline Grenada & 20 & 0.00 \\
\hline Belize & 3 & 0.00 \\
\hline Venezuela (Bolivarian Republic of) & 3 & 0.00 \\
\hline
\end{tabular}

Source: FAO. 2021c. Fishery and Aquaculture Statistics. Global production by production source 1950-2019 (FishStatJ).

In 2019, the 3.6 million tonnes of farmed Gracilaria (10.5 percent of all seaweeds) was contributed by 11 countries, comprising six countries or territories in Eastern and South-eastern Asia, two countries in South America, two countries in Northern Africa, and one country in Southern Europe (Table 5). The 3 million tonnes of farmed Porphyra (8.6 percent of all seaweeds) was contributed by five countries or territories in Eastern Asia (Table 6).

Besides the three major red seaweed genera, FAO statistics also record a small amount of unidentified red seaweeds cultivated in 2019 by two countries, comprising 5300 tonnes in India (Ranjan, 2021) and 5 tonnes in Chile (Buschmann et al., 2021).

Gracilaria are mostly used for agar production and abalone feed, whereas Kappaphycus/Eucheuma are mostly used to extract carrageenan (McHugh, 2003; FAO, 2018). As with alginate extracted from brown seaweeds, agar and carrageenan are seaweed-based hydrocolloids widely used in food and non-food industries. Gracilaria and Kappaphycus/Eucheuma are also consumed as human foods (e.g. salads and pickles) by coastal communities where they are produced. Porphyra are mostly used as human foods (e.g. soup ingredient and sushi wrap). 
Table 5: Gracilaria cultivation production, 2019

\begin{tabular}{l|r|r}
\multirow{2}{*}{ Country/area } & \multicolumn{2}{|c}{ Gracilaria cultivation } \\
\cline { 2 - 3 } & $\begin{array}{c}\text { Tonnes } \\
\text { (wet weight) }\end{array}$ & Share of world (\%) \\
\hline World & $\mathbf{3 6 3 9 8 3 3}$ & $\mathbf{1 0 0 . 0 0}$ \\
\hline Asia & $\mathbf{3 6 1 7 8 2 8}$ & $\mathbf{9 9 . 4 0}$ \\
\hline China & 3480850 & 95.63 \\
\hline Indonesia & 123000 & 3.38 \\
\hline Viet Nam & 11150 & 0.31 \\
\hline Republic of Korea & 1769 & 0.05 \\
\hline Taiwan Province of China & 976 & 0.03 \\
\hline Philippines & 83 & 0.00 \\
\hline Latin America and the Caribbean & $\mathbf{2 1 7 0 2}$ & $\mathbf{0 . 6 0}$ \\
\hline Chile & 21672 & 0.60 \\
\hline Brazil & 30 & 0.00 \\
\hline Africa & $\mathbf{3 0 3}$ & $\mathbf{0 . 0 1}$ \\
\hline Morocco & 273 & 0.01 \\
\hline Tunisia & 30 & 0.00 \\
\hline Europe & $\mathbf{0 . 1 3}$ & $\mathbf{0 . 0 0}$ \\
\hline Spain & 0.13 & 0.00 \\
\hline Sory
\end{tabular}

Source: FAO. 2021c. Fishery and Aquaculture Statistics. Global production by production source 1950-2019 (FishStatJ).

Table 6: Porphyra cultivation production, 2019

\begin{tabular}{l|r|r}
\multirow{2}{*}{ Country/area } & \multicolumn{2}{c}{ Porphyra cultivation } \\
\cline { 2 - 3 } & $\begin{array}{c}\text { Tonnes } \\
\text { (wet weight) }\end{array}$ & Share of world (\%) \\
\hline World & $\mathbf{2 9 8 4 ~ 1 2 3}$ & $\mathbf{1 0 0 . 0 0}$ \\
\hline Asia & $\mathbf{2 9 8 4 ~ 1 2 3}$ & $\mathbf{1 0 0 . 0 0}$ \\
\hline China & 2123040 & 71.14 \\
\hline Republic of Korea & 606873 & 20.34 \\
\hline Japan & 251200 & 8.42 \\
\hline Democratic People's Republic of Korea & 3000 & 0.10 \\
\hline Taiwan Province of China & 10 & 0.00 \\
\hline
\end{tabular}

Source: FAO. 2021c. Fishery and Aquaculture Statistics. Global production by production source 1950-2019 (FishStatJ).

\subsection{Green seaweeds (excluding green microalgae)}

Cultivation of green seaweeds has been small and on a downward trend since the early 1990s. The 16696 tonnes of world green seaweed cultivation in 2019 (merely 0.05 percent of all seaweeds) was less than half of the peak level in 1992 (38 556 tonnes), as opposed to the rapid growth in the cultivation of brown seaweeds (3-fold) and red seaweeds (15-fold) between 1992 and 2019.

FAO statistics record eight green seaweed ASFIS species items cultivated during 1950-2019; six of them had non-negligible production (i.e. greater than a half tonne) in 2019. The 16696 tonnes of world green seaweed cultivation in 2019 primarily comprised five ASFIS species items (i.e. Caulerpa spp; Monostroma nitidum; Enteromorpha [Ulva] prolifera; Capsosiphon fulvescens; and Codium fragile), whose 2019 production was lower than their peak levels during 1950-2019 (Table 7).

During 1950-2019, the 6404 tonnes of average annual aquaculture production of Caulerpa spp. was the highest among all green seaweeds, yet the production (almost entirely contributed by the Philippines) declined from 28704 tonnes in 1998 to 1090 tonnes in 2019.

In 2019, the 6321 tonnes of world cultivation of Monostroma nitidum (also known as green laver) was the highest among green seaweeds, yet the production (entirely contributed by the Republic of Korea) was much lower than its highest level during 1950-2019 (i.e. 17248 tonnes in 1992). 
Table 7: World green seaweed cultivation, 1950-2019

\begin{tabular}{|c|c|c|c|c|c|}
\hline \multirow{2}{*}{ Species } & \multirow{2}{*}{$\begin{array}{c}\text { Average } \\
\text { annual } \\
\text { cultivation } \\
\text { during } \\
\text { 1950-2019 } \\
\text { (wet tonnes) }\end{array}$} & \multicolumn{2}{|c|}{$\begin{array}{c}\text { Maximum annual } \\
\text { cultivation during } \\
1950-2019 \\
\end{array}$} & \multicolumn{2}{|c|}{ Cultivation in 2019} \\
\hline & & $\begin{array}{c}\text { Wet } \\
\text { tonnes }\end{array}$ & Year & $\begin{array}{l}\text { Wet } \\
\text { tonnes }\end{array}$ & Producing countries \\
\hline Green seaweeds & 14019 & 38556 & 1992 & 16696 & Total 6 countries \\
\hline 1. Caulerpa spp. & 6404 & 28704 & 1998 & 1090 & Philippines $(100 \%)$ \\
\hline 2. Monostroma nitidum & 3991 & 17248 & 1992 & 6321 & Republic of Korea (100\%) \\
\hline 3. Enteromorpha prolifera & 1367 & 12540 & 2008 & - & - \\
\hline 4. Capsosiphon fulvescens & 1134 & 7000 & 2018 & 3386 & Republic of Korea (100\%) \\
\hline 5. Ulva spp. & 515 & 2900 & 2005 & 2155 & South Africa (100\%) \\
\hline 6. Codium fragile & 494 & 5550 & 2014 & 3258 & Republic of Korea $(100 \%)$ \\
\hline 7. Green seaweeds nei & 114 & 863 & 1988 & 486 & $\begin{array}{r}\text { Viet Nam }(92.62 \%) \\
\text { Portugal }(7.2 \%) \\
\text { Spain }(0.18 \%) \\
\end{array}$ \\
\hline 8. Caulerpa racemosa & 0.06 & 2 & 2015 & - & - \\
\hline
\end{tabular}

Source: FAO. 2021c. Fishery and Aquaculture Statistics. Global production by production source 1950-2019 (FishStatJ). Notes: Green seaweeds exclude green microalgae. Species items are ranked according to the average annual production during 1950-2019. “-” indicates zero or no data. nei = not elsewhere included.

The 2155 tonnes of world cultivation of Ulva (also known as sea lettuces) in 2019 was also lower than its highest level during 1950-2019 (i.e. 14074 tonnes in 2008). The decline primarily reflects the decrease of Enteromorpha (Ulva) prolifera cultivation in China from 12540 tonnes in 2008 to a negligible level in 2019, whereas world cultivation of Ulva in 2019 comprised 2155 tonnes of Ulva spp. cultivated in South Africa (Table 7).

The Republic of Korea's 12965 tonnes of green seaweed cultivation in 2019, which comprised Monostroma nitidum, Capsosiphon fulvescens and Codium fragile (Table 7), was 78 percent of the world total.

Cultivated green seaweeds can be used as sea vegetables to prepare salads and other dishes. As manifested by their common or commercial names, Monostroma nitidum (also known as green laver) and Caulerpa lentillifera (also known as sea grape or green caviar) are considered delicacies. Similar to brown and red seaweeds, green seaweeds have many other applications, such as animal feeds (e.g. Ulva spp. cultivated in South Africa to feed abalone), biofertilizer/biostimulants, pharmaceuticals, cosmetics and waste treatment (McHugh, 2003; FAO, 2018).

\subsection{Stylized facts of seaweed cultivation}

In 2019 , average first-sale prices were USD $0.47 / \mathrm{kg}$ (wet weight) for brown seaweeds, USD 0.39/kg for red seaweeds and USD $0.79 / \mathrm{kg}$ for green seaweeds. The USD $0.89 / \mathrm{kg}$ of average price for Porphyra was the highest among the five major seaweed genera under cultivation, followed by Undaria (USD 0.75/kg), Gracilaria (USD 0.54/kg), Laminaria/Saccharina (USD $0.37 / \mathrm{kg}$ ) and Kappaphycus/Eucheuma (USD 0.21/kg).

On the supply side, economies of scale can help lower production cost, which is reflected by the lowest prices for the two largest seaweed genera, Laminaria/Saccharina and Kappaphycus/Eucheuma. In addition, low labour and capital costs are key to reducing the cost of seaweed cultivation (Cai, Hishamunda and Ridler, 2013), as indicated by the lower price of Kappaphycus/Eucheuma compared to Laminaria/Saccharina. On the demand side, generally speaking, seaweeds used as human foods tend to be more valuable than those employed for industrial applications. 
Many seaweeds collected from wild habitats have yet to be cultivated substantially; furthermore, not all wild seaweeds are suitable for cultivation. FAO statistics recorded 36 seaweed ASFIS species items with non-negligible wild production in 2019, among which 21 species items had no corresponding cultivation production. ${ }^{11}$ These 21 species items include several brown seaweeds that accounted for nearly half of wild seaweed production in 2019. Most of them were kelp species under the order Laminariales, including:

- 247312 tonnes of Lessonia kelps, which were collected in two countries in South America: Chile (245 269 tonnes) and Peru (2 043 tonnes).

- 75155 tonnes of Ascophyllum nodosum (also known as North Atlantic rockweed), which were collected in three countries in Northern Europe and one country in Northern America: Ireland (28 000 tonnes), Norway (18 949 tonnes), Iceland (15 551 tonnes) and Canada (12 655) tonnes.

- 51624 tonnes of Laminaria hyperborea (also known as North European kelp), which were collected in five European countries: Norway (36 771 tonnes), France (12 939 tonnes), Ireland (1 400 tonnes), the Russian Federation (430 tonnes) and Iceland (84 tonnes).

- 40100 tonnes of Laminaria digitata (also known as sea tangle), which were collected in two European countries: France (38 202 tonnes) and Iceland (1 898 tonnes).

In 2019, the 11.7 million tonnes of world production of carrageenan-containing seaweeds (carrageenophytes) was almost entirely supplied by Kappaphycus/Eucheuma cultivation in tropical areas. There were 62961 tonnes of wild collection of another five carrageenophytes in South America:

- 28672 tonnes of Sarcothalia crispata collected in Chile.

- 26644 tonnes of Gigartina skottsbergii collected in Chile;

- 2937 tonnes of Mazzaella laminarioides collected in Chile;

- 2364 tonnes of Gymnogongrus furcellatus collected in Chile; and

- 2344 tonnes of Chondracanthus chamissoi collected in Peru (1 511 tonnes) and Chile (833 tonnes).

These five carrageenophytes have no record of cultivation production in FAO statistics, which indicate that they have not been substantially cultivated.

Similarly, the 3.7 million tonnes of world production of agar-containing seaweeds (agarophytes) in 2019 was almost entirely supplied by Gracilaria, which were mostly provided by cultivation with a small amount (53 955 tonnes) resulting from wild collection in Chile. Another three agarophytes had only wild collection but no cultivation production recorded in FAO statistics:

- 1284 tonnes of Gelidium spp. collected in South Africa (735 tonnes), Chile (309 tonnes), Spain (232 tonnes) and Taiwan Province of China (8 tonnes);

- 158 tonnes of Gelidium corneum collected in France; and

- 1 tonne of Pterocladia lucida collected in New Zealand.

\footnotetext{
${ }^{11}$ This could partly reflect imperfect data (e.g. existing cultivation production not recorded or distinctly revealed in FAO statistics). Yet such cases are usually associated with low or concentrated production.
} 


\subsection{Microalgae}

Microalgae are microscopic algae usually invisible to the naked eye. While seaweeds are marine organisms, microalgae are phytoplankton found in both freshwater and marine systems. Microalgae comprise a variety of unicellular algae species, such as green microalgae (Chlorophyceae; e.g. Chlorella spp.) (Dixon and Wilken, 2018), diatoms (Bacillariophyceae), ${ }^{12}$ Nannochloropsis spp. (Chua et al., 2020), Schizochytrium spp. (EFSA NDA Panel, 2020), Crypthecodinium spp. (Mendes et al., 2009), to name a few closely related to aquaculture. Cyanobacteria (also known as blue-green algae), such as spirulina ${ }^{13}$ (including about 15 species under two genera, Spirulina and Arthrospira; Habib et al., 2008), are usually deemed part of microalgae (Hill, 2017).

Commercial microalgae production is rather small compared to seaweeds. The only wild production of microalgae recorded in FAO statistics was that of Spirulina (Arthrospira) in Mexico from 1962 until 1993, with a maximum production of 4375 tonnes in 1989.

Substantial microalgae cultivation recorded in FAO statistics started in 2003 with 16483 tonnes of Spirulina (Arthrospira) cultivated in China. Global microalgae cultivation reached 93756 tonnes in 2010, yet it declined to 56456 tonnes in 2019, which mostly reflected the change of spirulina cultivation in China.

The 56456 tonnes of world microalgae production in 2019 was supplied primarily by 56208 tonnes of Spirulina (Arthrospira), cultivated in ten countries, and four green microalgae (a total of 248 tonnes), cultivated in four countries (Table 8).

It should be noted that as microalgae cultivation tends to be regulated and monitored at the national or local level, separately from aquaculture, FAO statistics may miss substantial microalgae production in some countries, including Australia, Czechia, Iceland, India, Israel, Italy, Japan, Malaysia, Myanmar and the United States of America (FAO, 2020a).

Table 8: Microalgae cultivation, 2019

\begin{tabular}{|c|c|c|c|c|c|c|c|}
\hline \multirow[b]{2}{*}{ Country/area } & \multirow[b]{2}{*}{$\begin{array}{l}\text { Microalgae } \\
\text { (tonnes) }\end{array}$} & \multirow{2}{*}{$\begin{array}{c}\text { Spirulinal } \\
\text { Arthrospira } \\
\text { (tonnes) }\end{array}$} & \multicolumn{5}{|c|}{ Green microalgae (tonnes) } \\
\hline & & & Total & $\begin{array}{c}\text { Haematococcus } \\
\text { pluvialis }\end{array}$ & $\begin{array}{l}\text { Chlorella } \\
\text { vulgaris }\end{array}$ & $\begin{array}{l}\text { Tetraselmis } \\
\text { spp. }\end{array}$ & $\begin{array}{l}\text { Dunaliella } \\
\text { salina }\end{array}$ \\
\hline World & 56456 & 56208 & 248 & 242 & 4.77 & 1.45 & $\mathbf{0 . 2 2}$ \\
\hline 1. China & 54850 & 54650 & 200 & 200 & & & \\
\hline 2. Chile & 903 & 861 & 42 & 42 & & & \\
\hline 3. France & 207 & 201 & 6.22 & & 4.77 & 1.45 & \\
\hline 4. Greece & 142 & 142 & & & & & \\
\hline 5. Tunisia & 140 & 140 & & & & & \\
\hline $\begin{array}{l}\text { 6. Burkina } \\
\text { Faso }\end{array}$ & 140 & 140 & & & & & \\
\hline $\begin{array}{l}\text { 7. Central } \\
\text { African } \\
\text { Republic }\end{array}$ & 50 & 50 & & & & & \\
\hline 8. Chad & 20 & 20 & & & & & \\
\hline 9. Bulgaria & 2.65 & 2.65 & & & & & \\
\hline 10. Spain & 1.52 & 1.30 & 0.22 & & & & 0.22 \\
\hline
\end{tabular}

Source: FAO. 2021c. Fishery and Aquaculture Statistics. Global production by production source 1950-2019 (FishStatJ).

12 www.biologyonline.com/dictionary/diatom

${ }^{13}$ Under currently accepted taxonomic classification, main species in spirulina cultivation belong to the genus Arthrospira. However, the name of "spirulina" remains widely used, and FAO statistics maintain the use of "Spirulina" despite the reclassification (e.g. Spirulina platensis instead of Arthrospira platensis; S. maxima instead of A. maxima). For narrative convenience, this document refers to the genera Spirulina and Arthrospira collectively as "spirulina" (similar to the practice in Habib et al., 2008) or as "Spirulina (Arthrospira)". 
As opposed to seaweed cultivation that is mostly conducted in marine areas, commercial microalgae cultivation is primarily land-based operation. Three landlocked developing countries in Africa (Burkina Faso, Central African Republic and Chad) have microalgae productions recorded in FAO statistics (Table 8).

Most commercial microalgae cultivation is focused on the production of dried microalgae biomass (e.g. Chlorella or spirulina powder) as functional foods or dietary supplements and the extraction of various bioactive or biochemical compounds, such as (i) pigments as nutritional supplements (e.g. carotenes from Dunaliella and astaxanthin and canthaxanthin from Haematococcus); (ii) docosahexaenoic acid (DHA) from Crypthecodinium; (iii) polysaccharides as an additive to cosmetic products; and (iv) natural food colourants (e.g. spirulina as natural blue food colouring) (Spolaore et al., 2006; Barkia, Saari and Manning, 2019).

Microalgae have other promising applications in, for example, wastewater treatment, algae meal and algae oils, carbon sequestration and biofuels (Spolaore et al., 2006; Khan, Shin and Kim, 2018; Barkia, Saari and Manning, 2019; Ragaza, 2020). While these applications may not be fully commercialized, markets for many of them are growing and rapidly expanding. Substantial microalgae cultivation occurs in other aquaculture operations to produce feeds for animal species (see section 3.4), yet such production is usually not recorded in official statistics.

\section{SOCIAL, ECONOMIC AND ENVIRONMENTAL CONTRIBUTION OF ALGAE}

\subsection{Contribution to food, nutrition and human health}

Because most seaweed species have no intrinsic toxins, they are edible. Human consumption of seaweeds dates back centuries, with about 700 edible seaweed species (including around 195 brown seaweeds, 345 red seaweeds and 125 green seaweeds) documented (Pereira, 2016).

Coastal communities in many countries have cultural traditions of eating seaweeds. Laminaria/Saccharina, Porphyra and Undaria have become common foods in Eastern Asia and are widely and frequently consumed as soup ingredients, salads, sushi wraps and snacks, among others. They have been introduced in other countries as part of Asian cuisine and have gained increasing global popularity. Many seaweeds can be tasty foods when prepared and eaten properly, and they can be adapted to or integrated into modern culinary and dietary habits (Rhatigan, 2009; Mouritsen, 2013; Tinellis, 2014; Pérez Lloréns et al., 2018).

Being nutritious aquatic foods generally rich in dietary fibres, micronutrients and bioactive compounds (Holdt and Kraan, 2011), seaweeds are often treated as healthy, low-calorie food, particularly favoured by people who prefer low-carbohydrate or plant-based diets (Shannon and Abu-Ghannam, 2019). Some seaweed species, such as Palmaria palmata (also known as dulse) and Porphyra tenera, are known for their high protein content (Holdt and Kraan, 2011).

Multiple health benefits of seaweed consumption (e.g. improving gut health and reducing the risks of non-communicable diseases such as obesity and Type II diabetes) have been demonstrated by a large body of published research (Zhang et al., 2007; Wan-Loy and Siew-Moi, 2016; Pirian et al., 2017; Cherry et al., 2019; Gómez-Zorita, 2020).

In addition to direct human consumption, seaweeds are also processed into food additives or food supplements (McHugh, 2003; FAO, 2018). Japanese kelp (Laminaria japonica) was one of the earliest raw materials for producing monosodium glutamate, which is widely used as a flavour enhancer for umami taste (Milinovic et al., 2021). Agar extracted from Gracilaria and other agarophytes, 
carrageenan extracted from Kappaphycus/Eucheuma and other carrageenophytes, and alginate extracted from Laminaria/Saccharina and other brown seaweeds are seaweed-based hydrocolloids widely used as food additives to enhance the quality of a variety of foods. Additionally, seaweed extracts, such as iodine, fucoidan, fucoxanthin and phlorotannins, are used as food supplements for health benefits.

Non-toxic microalgae can be directly consumed as human foods. In Chad, the consumption of spirulina harvested from Lake Chad, primarily as a source of proteins and micronutrients, has helped improve the nutritional status of people in the landlocked, low-income country (Piccolo, 2012). The nutritional value and health benefits of microalgae have been well recognized (Jensen, Ginsberg and Drapeau, 2001; Habib et al., 2008). Various microalgae extracts are used as dietary supplements or food additives (see more details in section 2.5).

\subsection{Contribution to income, livelihood and social cohesion}

In 2019, the 34.7 million tonnes of world seaweed cultivation production for various food and non-food uses generated USD 14.7 billion first-sale value, primarily attributed to Laminaria/Saccharina (USD 4.6 billion), Porphyra (USD 2.7 billion), Kappaphycus/Eucheuma (USD 2.4 billion), Gracilaria (USD 2 billion) and Undaria (USD 1.9 billion).

Seaweed cultivation operations are usually labour intensive and employ many part-time or occasional workers. Thus, a large portion of the USD 14.7 billion of first-sale value became wages or incomes that supported the livelihoods of numerous households in coastal communities. Activities further downstream (e.g. post-harvest handling, distribution, processing and marketing) tend to generate more income and employment. For example, in the Philippines, it was estimated that the seaweed industry involved 100 000-150 000 seaweed farmers, 30 000-50 000 local consolidators, and more than 20000 small traders (Hurtado, 2013). The seaweed-carrageenan industry also created a large number of supportive and administrative jobs in laboratories and government offices.

According to UN Comtrade statistics, 98 countries earned USD 2.65 billion of foreign exchange in 2019 through exporting seaweeds (USD 909 million) and seaweed-based hydrocolloids (USD 1.74 billion) (Table 9).

Table 9: Export of seaweeds and seaweed-based hydrocolloids, 2019

\begin{tabular}{|c|c|c|c|c|c|c|c|c|}
\hline \multicolumn{3}{|c|}{$\begin{array}{l}\text { Seaweeds and seaweed-based } \\
\text { hydrocolloids }\end{array}$} & \multicolumn{3}{|c|}{ Seaweeds ${ }^{1}$} & \multicolumn{3}{|c|}{ Seaweed-based hydrocolloids ${ }^{2}$} \\
\hline Exporter & $\begin{array}{l}\text { Million } \\
\text { USD }\end{array}$ & $\begin{array}{c}\text { Share of } \\
\text { world } \\
(\%)\end{array}$ & Exporter & $\begin{array}{l}\text { Million } \\
\text { USD }\end{array}$ & $\begin{array}{c}\text { Share of } \\
\text { world } \\
(\%)\end{array}$ & Exporter & $\begin{array}{l}\text { Million } \\
\text { USD }\end{array}$ & $\begin{array}{l}\text { Share of } \\
\text { world }(\%)\end{array}$ \\
\hline 1. China & 578 & 21.79 & 1. Rep. of Korea & 278 & 30.55 & 1. China & 523 & 30.00 \\
\hline 2. Indonesia & 329 & 12.39 & 2. Indonesia & 218 & 24.01 & 2. Philippines & 214 & 12.28 \\
\hline 3. Rep. of Korea & 320 & 12.08 & 3. Chile & 86 & 9.43 & 3. Spain & 138 & 7.91 \\
\hline 4. Philippines & 252 & 9.52 & 4. China & 55 & 6.03 & 4. Chile & 123 & 7.06 \\
\hline 5. Chile & 209 & 7.87 & 5. Philippines & 38 & 4.23 & 5. France & 114 & 6.53 \\
\hline 6. Spain & 145 & 5.48 & 6. Ireland & 33 & 3.60 & 6. Indonesia & 110 & 6.34 \\
\hline 7. France & 124 & 4.68 & 7. Peru & 22 & 2.43 & $\begin{array}{l}\text { 7. United States of } \\
\text { America }\end{array}$ & 84 & 4.82 \\
\hline $\begin{array}{l}\text { 8. United States of } \\
\text { America }\end{array}$ & 102 & 3.85 & 8. Japan & 21 & 2.33 & 8. Germany & 76 & 4.39 \\
\hline 9. Germany & 82 & 3.11 & $\begin{array}{l}\text { 9. United States of } \\
\text { America }\end{array}$ & 18 & 1.98 & $\begin{array}{l}\text { 9. United } \\
\text { Kingdom }\end{array}$ & 65 & 3.75 \\
\hline $\begin{array}{l}\text { 10. United } \\
\text { Kingdom }\end{array}$ & 78 & 2.93 & 10. Canada & 18 & 1.97 & 10. Rep. of Korea & 43 & 2.45 \\
\hline Rest of the world & 432 & 16.30 & Rest of the world & 122 & 13.45 & Rest of the world & 252 & 14.47 \\
\hline World & 2652 & 100.00 & World & 909 & 100.00 & World & 1743 & 100.00 \\
\hline
\end{tabular}

Source: UN Comtrade (accessed on 7 April 2021).

Notes: 1. Seaweeds include cultivated and wild collected commodities under HS120220, HS120221 and HS120229. 2. Seaweed-based hydrocolloids include HS130231 (agar), HS130239 (primarily carrageenan) and HS391310 (alginate). 
The export of seaweeds and seaweed-based hydrocolloids accounted for a substantial portion of the export value of all fisheries and aquaculture products from the Philippines (22 percent) and the Republic of Korea (15 percent).

Seaweed cultivation makes a significant contribution to community cohesion and women's empowerment (Valderrama et al., 2013; Suyo et al., 2020; Suyo et al., 2021). The characteristics of seaweed cultivation (particularly the tropical species Kappaphycus/Eucheuma), such as labour intensive, low capital investments and simple farming technology, allow for the participation of many resource-poor households or vulnerable individuals (Lentisco and Needham, 2013).

Women often play a significant or leading role in seaweed cultivation and the value chain (Cai, Hishamunda and Ridler, 2013). In India, women were the first and primary adopters of seaweed farming, which offered them an income within a safe environment (Krishnan and Narayanakumar, 2013). In the United Republic of Tanzania, women have taken the initiative in seaweed farming, and are leaders both in seaweed cultivation and in adding value (Msuya, 2013). In the Philippines, women played significant roles in seaweed farming, especially in seeding and post-harvest treatments; they accounted for about 44 percent of the regular seaweed farming labour force and were the main source of casual labour (Hurtado, 2013).

\subsection{Environmental benefits and ecosystem services}

Seaweeds and microalgae provide important environmental benefits and ecosystem services (Campbell et al., 2019a). Seaweed cultivation does not need to directly use terrestrial land, freshwater, feed or fertilizer. Microalgae can be grown in freshwater or marine environments and cultivated in marginal land in desert and arid areas (Winckelmann et al., 2015).

By extracting nutrients (nitrogen and phosphorus) from surrounding waters and absorbing carbon dioxide, the photosynthetic process of seaweeds and microalgae can mitigate eutrophication, treat wastewater, reduce ocean acidification and capture/sequester carbon (Muraoka, 2004; Racine et al. 2021).

Seaweed and microalgae cultivation can contribute to the urgent need to address climate change through various mechanisms, including, among others, (i) algae-based products (e.g. human foods, animal feeds and fertilizers) that have a relatively low carbon footprint; (ii) capturing or sequestering carbon; and (iii) reducing methane emissions from cattle farming that uses certain seaweeds as feed supplement (Duarte et al., 2017; Hoegh-Guldberg et al., 2019; Roque et al., 2021). The potential of the contribution is, nevertheless, dependent upon multiple technical and socio-economic factors (see section 4.7).

Other direct or indirect environmental benefits and ecosystem services of seaweeds and/or microalgae include (i) providing habitats for fish and other marine organisms; (ii) serving as a buffer against strong wave action to protect the shoreline; (iii) reducing overfishing through providing alternative livelihoods to fishing communities; (iv) improving soil conditions and potentially reducing agricultural pesticides through seaweed-based biofertilizer or biostimulants (Nabti, Jha and Hartmann, 2017; El Boukhari et al., 2020); and (v) producing readily biodegradable goods and packaging (Chia et al., 2020); among others (Hasselström et al., 2018; Barbier et al., 2019).

\subsection{Contribution to aquaculture}

Besides the direct contribution to aquaculture production, seaweeds and microalgae also help facilitate other aquaculture activities. The ability of seaweeds to metabolize carbon dioxide and extract inorganic nutrients (nitrogen and phosphorus) from surrounding waters makes integration of seaweed cultivation with the farming of animal species an appealing production system, capable of increasing environmental and economic benefits through better nutrient recycling and more efficient use of farming areas. The 
potential of seaweeds as restorative aquaculture species has helped improve the public image of aquaculture and enhance the acceptability of aquaculture in environmental groups. ${ }^{14}$

The integrated multitrophic aquaculture (IMTA) system has the potential to generate not only environmental benefits but also economic profits (Soto, 2009). Some successful examples are (i) growing Gracilaria in shrimp or finfish ponds (Diatin, Effendi and Taufik, 2020); (ii) farming kelps and bivalves (e.g. mussels, oysters or scallops) together in open oceans, sometimes adding deposit feeders such as sea cucumbers (Mao et al., 2019; Fernández, Leal and Henríquez, 2019); and (iii) conducting mega-scale integrated aquaculture with over 240000 tonnes of annual production of more than 30 species (including kelp, scallops, oysters, abalone and sea cucumbers) in over $100 \mathrm{~km}^{2}$ of farming area that occupies two-thirds of a bay area (Fang et al., 2015). However, the application of IMTA faces multiple constraints and challenges (see section 4.4 for more information).

Seaweeds are used as main feed materials for abalone (Naidoo et al., 2006), sea urchins (Onomu et al., 2020) and, to a lesser extent, sea cucumbers (Xia et al., 2012). Seaweeds are also used as supplemental fish feed ingredients that provide necessary amino acids, beneficial polysaccharides, fatty acids, antioxidants, vitamins and minerals (Ismail, 2019).

Microalgae with high contents of lipids can be used to produce algae oils as a unique substitute of fish oils (Armenta and Valentine, 2013). Astaxanthin extracted from Haematococcus pluvialis, a green microalgae species, is used as a pigmentation enhancer in the salmon farming industry (Ambati et al., 2014).

Many hatcheries rely on microalgae cultivation to provide live feed organisms, directly or indirectly (e.g. through cultivating zooplankton), as a first feed and for nursing the larvae of fish, molluscs, crustaceans or other aquatic animals (Lavens and Sorgeloos, 1996). Microalgae produced as such are intermediate aquaculture products that are usually not recorded in official statistics.

Indeed, an important part of pond culture management is to monitor and cultivate microalgae to maintain good water quality and provide natural food for target species (Hill, 2017; Tacon, 1988). As pond culture is the main aquaculture grow-out system in freshwater or brackish-water environments for many major aquaculture species (e.g. carp, tilapia, catfish and shrimp), the hidden microalgae production, while not recorded in official statistics, tends to be enormous.

\section{ISSUES, CONSTRAINTS AND CHALLENGES}

There are vast areas suitable for seaweed and microalgae cultivation (Lehahn, Ingle and Golberg, 2016; Theuerkauf et al., 2019). ${ }^{15}$ Reported experiences in Eastern and South-eastern Asia indicate that seaweed and microalgae cultivation can become robust industries that generate benefits and contributions. However, further development of seaweeds and microalgae in global aquaculture faces multiple issues, constraints and challenges.

\footnotetext{
14 www.3blmedia.com/News/Oceans-2050-Leads-Global-Effort-Quantify-Seaweed-Carbon-Sequestration

${ }^{15}$ Researchers in Norway believe that mid-Norway alone has enough marine areas available to cultivate 20 million tonnes of seaweed biomass a year. https://www.sintef.no/en/latest-news/2020/seaweeds-may-become-aprofitable-piece-in-the-green-transition-

jigsaw/\#: :text=Researchers\%20believe \%20that $\% 20$ in $\% 20$ Mid,will\%20be $\% 20$ required $\% 20$ for $\% 20$ cultivation.
} 


\subsection{Limited or uncertain demand for seaweeds}

Expansion in seaweed production would need to be accommodated by increases in seaweed demand. One way is to increase seaweed consumption as human foods, which tends to utilize seaweeds efficiently and generate more income for seaweed farmers.

Although most seaweed production in Eastern Asia is consumed directly as human foods, people outside Eastern Asia generally have low or little exposure to or preference over seaweed consumption. The versatility and variety of many seaweeds suggest that they can be utilized in a broad range of food products, adding healthy, low calorie, nutrient dense opportunities for food manufacturers and distributors. However, demand for these applications remains low in spite of seaweed's nutritional value and health benefits and various ongoing efforts in promoting its consumption, particularly in Europe and Northern America (van den Burg, Dagevos and Helmes, 2021; UCTV, 2019).

Food safety concerns have been a primary issue deterring the consumption of aquatic foods (Ahern, Thilsted and Oenema, 2021). The consumption of wild and cultivated seaweeds and microalgae could also contribute to the exposure of certain food safety hazards (e.g. heavy metals or microcystin contaminations) or incur health risks from excessive intake of certain elements (e.g. iodine) (Bouga and Combet, 2015).

Many factors can affect the presence of food safety hazards in seaweeds and microalgae, including species/strain, physiology, season, location, harvesting method and post-harvest treatment, among others (Banach, Hoek-van den Hil and van der Fels-Klerx, 2020). Concerns and uncertainties over the safety of algae products pose a great challenge to the promotion of their consumption in new markets where food safety guidelines or regulations tend to be stringent for precautionary purposes (Lähteenmäki-Uutela, Rahikainen and Camarena-Gómez et al., 2021; ANSES, 2020).

While the cultivation of many seaweed species (e.g. Porphyra, Undaria and Laminaria/Saccharina) has been mostly driven by direct human consumption, the development of Kappaphycus/Eucheuma cultivation indicates that significant development of seaweeds (or algae in general) could be driven by applications other than direct human consumption. However, it is difficult to replicate the success of Kappaphycus/Eucheuma for all seaweeds because of the lack of key elements, such as (i) being a competitive raw material to produce a unique product with widespread applications that are difficult to replace with substitute products and (ii) availability of abundant farm sites and a large suitable labour force to produce the material at low cost.

Many non-food applications of seaweeds (e.g. pharmaceutical, nutraceutical, cosmetic, animal feed, biofertilizer/biostimulant, bio-packaging, textile fibre, carbon capture or sequestration, biofuel, among others) are promising, yet they face technical, economic and/or market constraints and challenges. It is unclear which of the application(s) will become the main driving force(s) behind the next major breakthrough in seaweed development, comparable to the success of Laminaria/Saccharina or Kappaphycus/Eucheuma (Cai et al., 2021).

\subsection{Limited or reduced availability of suitable farm sites nearshore}

Most seaweeds are grown close to the surface of the water in order to have sufficient sunlight for photosynthesis; therefore, they are usually cultivated in nearshore areas for operational and logistic conveniences. Nearshore operations tend to be less expensive in terms of both investment and operating costs. However, multiple factors pose constraints or challenges to seaweed cultivation in nearshore areas, including, among others, (i) competition for nearshore areas from urban development, recreation, fishing, fish farming and/or other activities; (ii) pollution in nearshore waters; and (iii) rising seawater temperatures. 
Cultivating seaweeds further offshore can help overcome the nearshore constraints, and seaweed cultivation could be integrated with other offshore activities such as wind energy generation (van den Burg et al., 2016). However, seaweed cultivation in the open ocean faces the challenges of technical feasibility (e.g. strong cultivars are needed to withstand strong waves; novel farming systems, such as the tube net for Kappaphycus/Eucheuma cultivation, are needed to protect seaweeds from strong waves; new skills, such as swimming, are needed to operate in deep-water farm sites; and enhanced management capacity is needed to safeguard and monitor the operation), economic viability, and the general lack of regulations on offshore aquaculture (Msuya, 2013; van den Burg et al., 2016; Liu et al., 2019; Bak, Gregersen and Infante, 2020).

\subsection{Shortage of labour}

Seaweed cultivation usually entails a large amount of labour in planting, daily maintenance, harvesting and post-harvest handling, with a seasonal or occasional demand (e.g. a large number of workers are needed for a short time period to harvest seaweeds at the optimal time to ensure desirable quality).

Plantation-style Kappaphycus/Eucheuma farms were established (e.g. in India and the Philippines) by carrageenan processors to gain better control over the raw material production. Yet they did not survive the competition of small, family-run farms. One of the main reasons was that highly flexible labour is needed to cultivate seaweeds on the cyclical time scales of tides and the moon, which made it difficult to pay workers stable wages (Valderrama et al., 2013).

The lack of suitable labour (low cost, flexible and stable supply) has been a major constraint over seaweed cultivation in developed regions (McHugh, 2003). Labour shortages also pose challenges to seaweed cultivating countries in developing regions on their paths towards a more developed and urbanized economy, as economic developments create more attractive employment opportunities in other sectors (e.g. tourism) than laborious and strenuous jobs in seaweed farming, particularly for the younger generation (Davis, 2021). More automated farming systems and technologies can help address labour shortages and improve occupational health but would tend to increase production costs (Liu et al., 2019).

\subsection{Constraints over integrated farming systems}

Notwithstanding its conceptual appeal and successful applications (see section 3.4), technical, economic and institutional constraints complicate the integration of seaweed cultivation with other aquaculture activities (Barrington, Chopin and Robinson, 2009; Troell, 2009; Hughes and Black, 2016). A recent study on the suitability of integrated multitrophic aquaculture (IMTA) in Europe identified constraints over IMTA in various aspects, including biological, conflicts, environmental, interest, legislation, market, operational, research and development, and vandalism (Kleitou, Kletou and David, 2018).

Technically, IMTA is a complex aquaculture system whose performance is dependent upon the balance of a wide range of interactions among cultivated species or between the organisms and their physical and chemical environment (Granada et al., 2018). A finfish or bivalve farmer may lack expertise or experience to cultivate seaweeds (and vice versa), let alone adopting appropriate farming protocols for all integrated species (e.g. stocking densities and biosecurity measures) to maintain a well-functioning ecosystem (Hughes and Black, 2016).

In an IMTA system, infrastructure and operation needed for cultivating one species may impede that of another integrated species. For example, the suspended system for cultivating seaweeds may alter water flow in a way that is undesirable to finfish cage farming nearby; seaweed longlines may interfere with the access of large vessels to finfish cages; finfish cages may attract herbivorous fishes grazing on seaweeds; and bivalves and their growing facilities may damage the fronds of seaweeds (Hughes and Black, 2016; Lance et al., 2017; Campbell et al., 2019a). 
Economically, IMTA systems, particularly large-scale operations, encounter the challenge of marketing multiple products along different value chains. While a diversified species composition in an IMTA system may help reduce the impacts of price fluctuations of individual species, the aforementioned complexities of the system would tend to increase the operational costs, and low-valued seaweeds may not offer enough financial incentive for finfish farmers to alter their business models (Troell, 2009).

An IMTA system also tends to have less flexibility in planning production according to market demands. For example, when facing an increase in seaweed price and a decline in bivalve price, an IMTA farmer may not have the same flexibility as in monoculture systems to increase the stocking density of seaweed and reduce that of bivalves, as doing so could disrupt the balanced ecosystem needed for a well-functioning IMTA system.

Institutionally, finfish farmers tend to lack incentives to integrate seaweeds into their farming systems if regulations do not force them to internalize the cumulative impacts of their farming operations on the ecosystem at larger scale (fjords, channels or whole bays) and do not allow them to benefit from the positive impacts of seaweeds on water quality (e.g. increasing the number of fish allowed to be reared) (Barrington, Chopin and Robinson, 2009; Troell, 2009). Integration may also be hindered by a lack of regulations that facilitate collaboration between site owners who produce different species.

\subsection{Low or declined seedling quality}

Seedling production is key to successful and sustainable seaweed farming. Large-scale Porphyra cultivation became feasible only after its unusual life cycle (particularly the shell-boring Conchocelis phase) was understood in the early 1950s and the technology of growing Porphyra seedlings on oyster shells in land-based facilities was developed (McHugh, 2003). The breakthrough in rearing summer seedlings in hatcheries helped jump-start rapid growth of kelp farming in China in the late 1950s, and continuing efforts in improving kelp seedlings (e.g. through hybridization) have not only increased the productivity of kelp cultivation but also expanded kelp cultivation to geographical areas with warmer seawater temperatures (e.g. Fujian Province in South-eastern China) (Hu et al., 2021).

The quality of seedlings has become increasingly crucial under deteriorating farming environments, such as rising seawater temperatures and more frequent and severe disease outbreaks. Outsourcing good quality seed stocks from specialized hatcheries is a common practice in aquaculture, yet mainstreaming the business model could be difficult for some seaweeds (e.g. Kappaphycus/Eucheuma) cultivated by numerous smallholder farmers who can easily obtain cultivars through vegetative propagation from their own harvest.

Improper management or constraints over seedling production, including the use of inbred stocks or repeated vegetative propagation, can lead to trait degeneration and the consequent loss of agronomic value of a farmed type ${ }^{16}$ due to possible reduced growth, lowered quality and higher susceptibility to diseases, among others (Loureiro, Gachon and Rebours, 2015). Low or declined quality of seedlings could motivate the introduction of non-native seaweed species or genotypes, which pose risks to biodiversity and biosecurity.

Genetic improvement technologies, such as strain selection (Hwang, Ha and Park, 2017), selective breeding (Hwang et al., 2019), hybridization (Su et al., 2020), micropropagation (also known as tissue culture) (Reddy et al., 2017) and genetic markers (Yong, Chin and Rodrigues, 2016), can help improve

\footnotetext{
${ }^{16}$ A farmed type is a cultured aquatic organism that could be a strain, variety, hybrid, triploid, monosex group, another genetically altered form, or wild type.
} 
seedling quality and production efficiency. However, these tend to be technical and financially demanding and often require public support.

While seaweed breeding programmes and progress have played a vital role in the development of seaweed cultivation in Eastern Asia (Hwang et al., 2019), a lack of genetic improvement persists in tropical red seaweeds (e.g. Kappaphycus/Eucheuma) that are primarily multiplied by vegetative propagation. While distinct morphotypes of Kappaphycus/Eucheuma are recognized, the genetic basis of these morphotypes is inadequately researched and poorly understood.

\subsection{Miscellaneous issues or constraints over seaweed cultivation and value chains}

Other significant issues hindering seaweed cultivation and value chains include (i) deteriorating farming environments because of climate change, such as rising seawater temperatures, increasing extreme weather conditions and more voracious grazing of predators (Smith, 2017); (ii) more frequent and severe disease outbreaks (Ward et al., 2020); (iii) high transportation costs; (iv) high intermediary costs; (v) low and fluctuating market prices, including uncertain export prices due to exchange rate fluctuations; (vi) low incomes for seaweed farmers; (vii) suboptimal practices (e.g. premature harvesting) owing to financial constraints or unstable market conditions; (viii) low quality due to inappropriate post-harvest handling; and (ix) lack of value addition (Cai, Hishamunda and Ridler, 2013).

\subsection{Environmental/ecosystem impacts or risks}

As extractive aquaculture species, seaweeds tend to be more eco-friendly than fed aquaculture species. However, improperly managed seaweed cultivation could negatively affect the environment or ecosystem through (i) spreading diseases and parasites; (ii) releasing reproductive materials of domesticated or non-native species that may contaminate the genetic integrity of local species; (iii) slowing water flow, which may hinder sediment transport and alter marine chemistry; (iv) competing for light and nutrients with other marine organisms; (v) causing environmental degradation through the construction of the farming system (e.g. destroying mangroves for wooden stakes or damaging the benthic ecosystem by clearing up the sea floor or using stakes or anchors); and (vi) causing pollution during operation (e.g. loss/discard of cultivation materials or generation of noise) (Campbell et al., 2019a; Hurtado, Neish and Critchley, 2019).

The environmental benefits and ecosystem services of seaweed cultivation may be discounted by the environmental or ecological footprint along the seaweed supply chain. For example, while seaweed cultivation normally does not need to use freshwater, seaweed processing, such as washing seaweeds or extraction of target compounds (e.g. agar), can be freshwater-intensive operations (McHugh, 2003).

Fast-growing seaweeds can capture carbon more quickly than trees; however, a large portion of captured carbon may not be permanently sequestered if seaweeds are harvested after a relatively short growing cycle (usually less than one year) (Krause-Jensen and Duarte, 2016). Cultivating seaweeds and burying them in the deep ocean can help realize their full potential in carbon sequestration, yet such operations face the challenges of economic viability and uncertain environmental impacts.

\subsection{Issues and constraints over microalgae cultivation}

Despite efforts in promoting microalgae as a new source of human food to fight hunger and malnutrition (UNGA, 2015; IIMSAM, 2021), including the efforts of FAO (Habib et al., 2008; Piccolo, 2012), global human consumption of microalgae mostly occurs through high-end food supplement products (e.g. Chlorella or spirulina powder) supplied by the nutraceutical industry (see details in section 2.5).

Factors that constrain the use of microalgae in human foods include (i) unappealing taste or colour; (ii) potential heavy metals and/or microcystins contaminations under poorly managed cultivation; 
(iii) potential side effects caused by microalgae intake (e.g. allergies and gastrointestinal problems); and (iv) relatively high prices of quality microalgae products (Barkia, Saari and Manning, 2019).

While microalgae can grow very fast under suitable conditions, the productivity of large-scale microalgae cultivation in open systems (e.g. ponds or raceways) tends to be hampered by various technical factors, including (i) contaminants (i.e. non-target microalgae); (ii) viruses, pathogens, parasites and predators; (iii) insufficient nutrients or carbon dioxide; (iv) insufficient sunlight due to self-shading from high cell density; (v) photooxidation and death due to excess accumulation of oxygen during the day; and (vi) significant shifts in culture $\mathrm{pH}$ with photosynthesis (absorbing carbon dioxide) during the day and respiration (releasing carbon dioxide) at night (Barkia, Saari and Manning, 2019).

Closed cultivating systems (e.g. photobioreactors) provide better controlled cultivation environments, but they are expensive to build and operate (Barkia, Saari and Manning, 2019). The high cost of harvesting (i.e. dewatering) and refining cultivated microalgae biomass is another factor contributing to the high production cost of microalgae, which is a main constraint over viable commercialization of microalgae biofuel production (Lam and Lee, 2012).

\subsection{Algae blooms}

The fast-growing nature of algae, desirable in aquaculture notwithstanding, can cause algae blooms in wild habitats. Harmful microalgae blooms, such as red tides along coastal regions (Anderson, Cembella and Hallegraeff, 2012; NOAA, 2021) and blue-green algae (cyanobacteria) blooms in inland waters (Jia, Zhang and Dong, 2019), can deteriorate water quality, disrupt aquatic ecosystems and cause water and food contaminations that endanger the health of aquatic animals and humans (Sanseverino et al., 2016).

Macroalgae blooms, such as Sargassum blooms aka golden tides (Byeon, Oh and Kim et al., 2019) and Ulva blooms aka green tides (Gladyshev and Gubelit, 2019), can also lead to costly environmental nuisances. For example, holopelagic Sargassum blooms that began in the southern tropical Atlantic have caused massive amounts of Sargassum to intermittently wash ashore on African and Caribbean coasts since 2011 (Wang et al., 2019; Desrochers et al., 2020; Godínez-Ortega et al., 2021), causing detrimental impacts on coastal ecosystems, tourism and fisheries. In the open ocean, floating Sargassum mats, primarily composed of a mix of $S$. fluitans and $S$. natans, are considered as a natural reserve, attracting many species of marine fauna and flora and acting as a nursery. However, when reaching coastal areas, the huge amount of Sargassum biomass becomes a menace to the tourist industry, disturbs fisheries and nearshore ecosystems, and negatively affects coastal communities' livelihoods.

Most algae blooms are caused by a rapid proliferation and accumulation of wild algae under conducive conditions for growth (temperatures, salinity, sunlight, nutrients, etc.). Nutrient pollution, which can come from diverse sources (e.g. agricultural runoff, aquaculture effluent, urban waste, industrial pollution, and fossil fuel combustion), ${ }^{17}$ tends to be a main culprit leading to algae blooms.

Removing large amounts of algae biomass caused by blooms tends to be difficult and costly. Utilizing the biomass to produce feed, fertilizer, human foods and other products can offset some of the expenses incurred to manage the blooms. However, multiple constraints and challenges, such as the lack of markets, inadequate processing capacity, and uncertain quantity and undesirable quality of the biomass (e.g. the high arsenic contents in wild Sargassum along the Caribbean coasts), complicate the development of an industry based on biomass from algae blooms (Desrochers et al., 2020; Devault et al., 2020).

\footnotetext{
${ }^{17}$ www.wri.org/our-work/project/eutrophication-and-hypoxia/sources-eutrophication\#urban
} 
Measures to reduce nutrient pollution, such as preventing soil erosion (e.g. caused by deforestation), managing nutrient supply by mass balance (i.e., crop supplied precisely with what it needs) and appropriate wastewater treatment, are fundamental means to address algae blooms. Algae cultivation, through its biosorption and bioremediation impacts on eutrophication, can help prevent or mitigate wild algae blooms. In addition, development of the algae sector can generate market demand and processing capacity to facilitate the economic utilization of biomass from wild algae blooms.

However, improper practices in seaweed cultivation could contribute to macroalgae blooms. For example, the recurrent blooms of Enteromorpha (Ulva) prolifera in the Yellow Sea and the East China Sea originated from the coastal area that accounted for 95 percent of Porphyra yezoensis cultivation in China (Hu et al., 2010; Zhang et al., 2019a). E. prolifera is a nuisance species that grows on bamboo rafts and rope nets used to cultivate $P$. yezoensis. Cleaning of the cultivating rafts or heavy storms can release considerable amounts of E. prolifera into the water. As the $P$. yezoensis farming area more than doubled between 2007 and 2008, a massive E. prolifera bloom (covering $2400 \mathrm{~km}^{2}$ ) occurred in the Yellow Sea in 2008 and caused significant economic losses (Hu et al., 2010).

Eco-friendly practices, such as forbidding improper introduction of invasive alien species and avoiding disposal of large amount of epiphytes into the water, can help minimize the potential contribution of seaweed cultivation to algae blooms. For example, adjustments of harvest timing and methods of $P$. yezoensis cultivation has helped reduce the scale of E. prolifera blooms in the Yellow Sea (Zhang et al., 2019b).

Microalgae cultivation, which usually rears non-toxic microalgae in self-contained farming systems, presents low risks of causing harmful algae blooms in wild habitats. However, precautionary measures should be taken to minimize such risks, especially as genetic modification has been considered as a means to increase the productivity of microalgae cultivation (Henley et al., 2012; Kumar et al., 2020).

\section{LESSONS LEARNED AND WAY FORWARD}

\subsection{Governance as foundation}

Science- and evidence-based laws, regulations and guidelines (environmental regulations, spatial planning, food safety standards, occupational health requirements, technical guidelines and good aquaculture practices, among others) on seaweeds and microalgae are essential to laying a solid foundation for the sector's sustainable development.

While it is usually the jurisdiction of individual countries to establish or adopt these criteria according to their socio-economic and environmental conditions and developmental priorities, the international and scientific communities can help generate and share global knowledge and experiences to facilitate informed decision-making in the process.

Governments, civil societies, international organizations and/or the industry can establish or facilitate community-based management (e.g. farmer groups) and market-based schemes (e.g. certification), which can become equally or more effective governing mechanisms in certain areas (e.g. fostering good practices, such as adopting proper stocking density, avoiding the littering of cultivation materials in the ocean, and not adding impurities during the post-harvest handling). 


\subsection{Market demand as driving force}

Market demand has been a key driving force behind algae sector development. The kelp boom in Scotland during the eighteenth century, an industry which employed over 100000 people at peak time, was driven by demand for raw materials to produce soda (sodium carbonate) and potash (potassium carbonate) (Kenicer, Bridgewater and Milliken, 2000).

Demand for raw materials to produce carrageenan created the Irish moss (Chondrus crispus) boom in Canada, starting around 1950 and lasting through the mid-1970s (Craigie, Cornish and Deveau, 2019), and later also fuelled the Kappaphycus/Eucheuma booms in the Philippines (from the mid-1970s to the early 2010s) and in Indonesia (from around 2000 to the mid-2010s) (Bixler and Porse, 2011).

Demand for healthy and tasty aquatic food has been the primary driving force behind the kelp boom in Eastern Asia, primarily China and the Republic of Korea, from the 1950s to the present day. The boom has been sustained or reinforced along the way by other market forces, such as the demand for brown seaweed extracts (iodine, alginate, mannitol, fucoidan, etc.) and the demand for fresh seaweeds to feed abalone (Hwang, Ha and Park, 2017; Zhang, 2018).

Nutritious, eco-friendly and versatile algae have great potential in a variety of food and non-food applications, yet the potential may not turn into immediate market demand because of a variety of constraints, such as low consumer exposure or preference, high production costs, market competition and stringent regulations. One example is the lack of commercial success in algae-based biofuel production (primarily because of high production costs and low fossil fuel price) in spite of much interest and substantial investments in the sector from the private and public sectors (van Iersel and Flammini, 2010; Lam and Lee, 2012; Chen et al., 2015).

Though attracting attention, many potential contributions of algae (e.g. health contributions, environmental benefits and ecosystem services) may not automatically lead to immediate market demand or subsequent business opportunities to attract profit-seeking private investments in the sector. Similarly, the valuable global externalities of seaweeds and microalgae (e.g. mitigating climate change through carbon sequestration) may not give local governments enough incentive to prioritize algae in development planning.

Therefore, market-based mechanisms, including carbon credits, nitrogen credits, blue bonds and green finance, among others, could be established to facilitate internalization of the positive externalities of algae (Jones, 2021). Coordinated support from governments, donors, civil societies and international organizations is crucial to facilitating algae sector development and integration into global food systems.

Another crucial lesson learned from the history of global algae development is that over-reliance on a narrow range of applications (particularly industrial commodities) can be risky or unsustainable. For instance, the aforementioned kelp boom in Scotland went into a speedy decline in the early $1800 \mathrm{~s}$, as more economic ways to produce soda and potash were discovered (Kenicer, Bridgewater and Milliken, 2000). The rapid expansion of Kappaphycus/Eucheuma cultivation in tropical areas, which supplies much cheaper raw materials for carrageenan production, has rendered the Irish moss industry in Canada a similar boom-bust experience, and the decline of the industry (starting in the mid-1970s) has caused significant socio-economic repercussions (Eamer, 2016).

Utilization of algae (especially seaweeds) as human foods, particularly for local consumption, tends to be the most stable market force that can serve as a stabilizer for algae sector development. However, the inertia of dietary habits and consumer behaviours poses a major challenge to the development of markets for algae food products, especially in places with little algae production, consumption and 
culinary traditions. Forming or changing dietary habits tends to be a long-term process that entails joint efforts of stakeholders and experts in policy, business and scientific communities.

Despite anecdotal evidence of increasing global or local popularity of sushi and other seaweed-based food products (e.g. snacks, salads and desserts), there is a general lack of detailed information and knowledge of algae-based food market potential (particularly market price and volume), which is essential to informed decision-making in policy and planning for the development of seaweed cultivation. In-depth, comprehensive assessments of algae markets and value chains at the global, regional, national and subnational levels are needed to fill the gap.

\subsection{Innovation as game changer}

Science and innovations have been the main driving forces behind breakthroughs in seaweed or microalgae development. A few examples of notable innovations that have resulted in a rapid expansion of seaweed cultivation include: (i) innovations in seedling production, mentioned in section 4.5; (ii) development of longline cultivating systems for kelp farming; (iii) technology of extracting good quality agar from Gracilaria; and (iv) food-grade semi-refined carrageenan (McHugh, 2003).

Based upon scientific publication metrics, bioprospecting efforts between 1965 and 2012 resulted in a total of 3129 marine natural products or bioactive molecules from seaweeds (53 percent from red seaweeds; 39 percent from brown seaweeds; and 8 percent from green seaweeds). However, the steps from discovery to development have been slow to materialize (Leal et al., 2013; Leal et al., 2020).

Persistent and painstaking efforts in innovation and fostering close collaborations between the algae industry and the cross-disciplinary research community are needed to transform the extensive potential of seaweeds and microalgae into acceptable, available and affordable food or non-food products.

The public sector can facilitate the process by providing support for basic research on important topics, such as nutrition, genetic resources and diseases. There is a significant need for more research in controlled scientific studies with properly designed human trials, which will help determine the bioavailability of the many nutritional assets known to be present in seaweeds and their long-term effects on human health (Xi and Dragsted, 2019).

Limited knowledge of genetic diversity and inadequate integration of genetic analysis in seaweed breeding undermines the sustainability of seaweed production and their conservation. Improving knowledge of seaweed genetic diversity and taxonomy would assist in building a baseline for assessing the extinction risk of seaweed species given that only a minority of them are included in the IUCN Red List, and most of them have been classified as "Data Deficient".

Ice-ice disease and epiphyte infestation have been an enduring factor that hindered farmers in Zanzibar from cultivating more lucrative Kappaphycus alvarezii (Largo, Msuya and Menezes, 2020). With a general trend of deteriorating farming environments and declined seedling quality, global seaweed cultivation is subject to increasing risks of disease outbreaks (Hurtado, Montano and Martinez-Goss, 2013; Kim et al., 2014). The pressing needs are to (i) better understand the causes of pathogenic and physiological disease; (ii) improve methodologies for the characterization of pathogens; (iii) develop rapid and robust diagnostic techniques; and (iv) establish effective national and international biosecurity policies (Campbell et al., 2019b; Ward et al., 2020).

Public support (including financial incentives) is also needed to support the development and commercialization of innovations that tend to have significant technical, economic, environmental and/or social benefits. Examples of such innovations include, among others, (i) tube-net technique suitable for growing warm-water red seaweeds in areas with strong currents (Mantri, Shah and 
Thiruppathi, 2020); (ii) land-based tank culture systems that provide better-controlled environment conditions to optimize the quality, safety and traceability of seaweed products (Gadberry et al., 2019); (iii) species diversification and crop rotation that tend to help reduce the risk of disease, deter grazing by herbivores and improve crop yield (Grebe et al., 2019); (iv) technologies to prevent the contamination of non-target species in large-scale open systems of microalgae cultivation; (v) technologies that reduce the high cost of harvesting microalgae in large-scale cultivation, which has been a major constraint deterring investments in large-scale microalgae cultivation; (vi) resourceefficient biorefinery technologies that convert algae biomass into different products (Lange et al., 2020); (vii) product improvement, such as the removal of undesirable tastes, better texture, more appealing appearance and longer shelf-life; and (viii) integration of seaweeds in local cuisine and innovative recipes.

\subsection{Public support as enabling environment}

The private sector, particularly in countries with little seaweed production and consumption, may lack incentives to devote substantial, long-term efforts to the development of seaweed markets with uncertain prospects. Thus, public support is needed to increase the public recognition and appreciation of seaweeds as nutritious human foods and help establish dietary habits in seaweed consumption.

For example, with the safety and nutritional value of seaweeds ensured, public programmes, such as nutrition education and seaweeds on the menu of hospitals, schools and other public institutions, can be implemented to promote seaweed consumption, which will not only increase seaweed demand immediately but also help foster future seaweed consumers. Seaweeds are good for the health and wellness of those who are clinically unwell, and their nutritious characteristics and health benefits (e.g. fibre, texture, robust nutritional profile, essential nutrients and antioxidants) make them an ideal food for the elderly.

The public sector should create an enabling environment to facilitate the development of algae cultivation. For example, governments can recognize seaweed and/or microalgae cultivation as a development priority and use licensing, financial support and other mechanisms to help reward the sector for its environmental benefits and ecosystem services.

Governments, civil societies, international organizations and other public sector partners can help improve the algae sector performance by (i) raising public awareness of the sector's environmental and socio-economic contributions; (ii) generating and compiling information and knowledge on algae supply chains needed for informed decisions in public and private sectors; (iii) establishing effective mechanisms to facilitate innovations, capacity-building, technology transfer and knowledge-sharing; and (iv) fostering collaboration and partnership among policy, scientific and business communities.

Considering the significant regional imbalance in seaweed production and consumption, it may be worthwhile to establish a global programme on seaweeds, be it a general one for strengthening seaweed cultivation and the value chain or a specific one focused on addressing key issues (e.g. promoting seaweed consumption).

Seaweed and microalgae cultivation may be jump-started by different impetuses, yet it needs strong value chains to become sustainable. This is particularly important for project-driven seaweed or microalgae development. Healthy, strong and sustainable value chains need to be characterized by low transaction costs, less asymmetric information and effective risk-sharing mechanisms and ought to be inclusive. One key lesson learned in public support to promoting seaweed cultivation is that ignoring the socio-economic aspects of seaweed farming can lead to a lack of sustainability. Many seaweed development projects have "ended in failure" because of overlooking the "human factor" that concerns not only seaweed farmers but also other stakeholders (Ask, 2001). 


\subsection{FAO's roles}

FAO has conducted various projects that were either focused on seaweeds or that included seaweed development as a component; FAO has also generated and disseminated a number of information and knowledge products on algae; see Table 10 and Table 11 for some recent examples.

FAO's work on the Progressive Management Pathway for Improving Aquaculture Biosecurity (PMP/AB) (FAO, 2020b, 2020c, 2020d) can help establish a progressive, risk-based and collaborative management framework for seaweed farming biosecurity at the enterprise, national and international levels. A forthcoming FAO publication on diseases of aquatic organisms will include a section on seaweed.

FAO is developing a background document that identifies food safety hazards (chemicals, pathogens and toxins) linked to the consumption of seaweeds. The document would lay a foundation for further work in this area. FAO considers that there might be value in developing relevant Codex guidance on this subject and presented this issue for consideration in May 2021 during the 14th Session of the Codex Committee on Contaminants in Foods (JECFA Secretariats, 2021). The issue will be followed up by the Codex Alimentarius Commission.

As part of its work on aquatic genetic resources (FAO, 2019), FAO is developing an information system on the farmed types of aquatic genetic resources, including algae, which can help address the paucity of information of the genetic basis of seaweed cultivation.

FAO databases on global fisheries and aquaculture production have been a unique source of data and statistics on global wild and cultivated production of seaweeds and microalgae (under "aquatic plants"), which have been used extensively in the preparation of this document. More detailed information can be found in the factsheet on Global seaweeds and microalgae production, 1950-2019 (FAO, 2021d).

There is much room for improvement in FAO statistics on the production of seaweeds and microalgae, in terms of accuracy and completeness (e.g. broader country coverage and more disaggregate species composition). Information and knowledge on other parts of seaweed or microalgae supply chains (e.g. processing and consumption) is also inadequate. Continuing support from FAO Members is needed for FAO to improve the quantity and quality of data and information on seaweeds and microalgae.

Other areas of FAO work on the development of algae (primarily seaweed) cultivation and value chain may include, among others, (i) developing practical manuals on seaweed cultivation; (ii) establishing technical platforms to facilitate capacity-building, technology transfer and knowledge-sharing in key areas (farming systems and technology, genetic improvement, disease control, among others); (iii) supporting market development for utilizing seaweeds as human foods; and (iv) facilitating collaboration and cooperation among Members in strengthening governance for sustainable algae sector development. 
Table 10: Examples of recent FAO projects related to algae

\begin{tabular}{|c|c|c|c|}
\hline Time frame & Beneficiaries & Project & Focused areas \\
\hline \multicolumn{4}{|l|}{ Africa } \\
\hline $2016-2017$ & $\begin{array}{l}\text { Zanzibar, United Republic of } \\
\text { Tanzania }\end{array}$ & $\begin{array}{l}\text { TCP/URT/3601/C1: Support to Seaweed Diseases and Die-off } \\
\text { Understanding and Eradication in Zanzibar }\end{array}$ & $\begin{array}{l}\text { Biosecurity and disease } \\
\text { control }\end{array}$ \\
\hline 2014-2018 & Kenya; United Republic of Tanzania & $\begin{array}{l}\text { FMM/GLO/112/MUL: Baby } 4 \text { - Blue Growth Initiative in } \\
\text { Support of Food Nutrition Security, Poverty Alleviation and } \\
\text { Healthy Oceans }\end{array}$ & $\begin{array}{l}\text { Food security and nutrition; } \\
\text { poverty alleviation }\end{array}$ \\
\hline 2014-2015 & $\begin{array}{l}\text { Zanzibar, United Republic of } \\
\text { Tanzania }\end{array}$ & $\begin{array}{l}\text { TCP/URT/3401 (13/X/URT/220): Support to the Aquaculture } \\
\text { Subsector of Zanzibar }\end{array}$ & $\begin{array}{l}\text { Capacity-building; market } \\
\text { development; investment } \\
\text { planning }\end{array}$ \\
\hline \multicolumn{4}{|l|}{ Asia } \\
\hline 2019-2021 & Bangladesh & $\begin{array}{l}\text { TCP/BGD/3704 (19/I/BGD/238): Support to Seaweed } \\
\text { Cultivation, Processing and Marketing Through Assessment and } \\
\text { Capacity Development }\end{array}$ & $\begin{array}{l}\text { Sector development; } \\
\text { capacity-building }\end{array}$ \\
\hline 2001-2002 & Indonesia & $\begin{array}{l}\text { TFD-99/INS/003: Assistance for Fishermen's Group in the } \\
\text { Tidung Island to Establish a Small-scale Enterprise of Seaweed } \\
\text { Production }\end{array}$ & $\begin{array}{l}\text { Poverty alleviation; efficient } \\
\text { resource management }\end{array}$ \\
\hline $1992-1994$ & Philippines & PHI/89/004//01/12: Seaweed Production Development & Production \\
\hline $1988-1989$ & Thailand & $\begin{array}{l}\text { TCP/THA/8854 (8/III/THA/080): Seaweed Production and } \\
\text { Processing }\end{array}$ & Production and processing \\
\hline $1988-1995$ & Viet Nam & VIE/86/010//01/12: Seaweed Culture and Processing & Production and processing \\
\hline 1987 & China & $\begin{array}{l}\text { TCP/CPR/6759 (6/X/CPR/086): Workshop on Seaweed } \\
\text { Production }\end{array}$ & Production \\
\hline \multicolumn{4}{|c|}{ - } \\
\hline 2001-2004 & Brazil & $\begin{array}{l}\text { TCP/BRA/2907 and TCP/BRA/0065: Small-scale Seaweed } \\
\text { Farming in Northeast Brazil - Phase II of TCP/BRA/0065 }\end{array}$ & $\begin{array}{l}\text { Feasibility analysis; market } \\
\text { assessment; piloting }\end{array}$ \\
\hline $2017-2021$ & Chile & $\begin{array}{l}\text { GCP/CHI/039/GFF: Strengthening the Adaptive Capacity to } \\
\text { Climate Change in the Fisheries and Aquaculture Sector of Chile }\end{array}$ & Climate change adaptation \\
\hline
\end{tabular}




\begin{tabular}{|c|c|c|c|}
\hline Time frame & Beneficiaries & Project & Focused areas \\
\hline \multicolumn{4}{|l|}{ Caribbean } \\
\hline Forthcoming & $\begin{array}{l}\text { Dominica; Grenada; Saint Kitts and } \\
\text { Nevis; Trinidad and Tobago }\end{array}$ & $\begin{array}{l}\text { AMEXCID-CARICOM-FAO: Capacity Training (in Production } \\
\text { Practices, Post-production Practices and Accessing Credit), } \\
\text { Policy Creation and Establishment or Upscaling of Farms }\end{array}$ & Capacity-building \\
\hline 2020-2023 & Grenada and Saint Lucia & $\begin{array}{l}\text { GCP/RLA/230/IFA: Farmers' Organizations for Africa, } \\
\text { Caribbean and Pacific Countries Programme in the Caribbean } \\
\text { Region }\end{array}$ & $\begin{array}{l}\text { Food security and nutrition; } \\
\text { poverty alleviation }\end{array}$ \\
\hline 2020-2021 & Grenada and Saint Lucia & $\begin{array}{l}\text { UNJP/SLC/021/UNO: Building Effective Resilience for Human } \\
\text { Security in the Caribbean Countries - The Imperative of Gender } \\
\text { Equality and Women Empowerment in a Strengthened } \\
\text { Agriculture (and Related Agri/Fisheries Small Business) Sector } \\
\text { Project }\end{array}$ & Gender balance \\
\hline 2020-2021 & Saint Lucia & $\begin{array}{l}\text { TCP/STL/3702: Technical Assistance to Support UK Market } \\
\text { Penetration for Saint Lucian Agricultural Products }\end{array}$ & $\begin{array}{l}\text { Market development; food } \\
\text { safety }\end{array}$ \\
\hline 2019-2020 & Saint Lucia & $\begin{array}{l}\text { FMM/GLO/145/MUL: Empowering Women in Food Systems } \\
\text { and Strengthening the Local Capacities and Resilience of Small } \\
\text { Island Developing States (SIDS) in the Agrifood Sector }\end{array}$ & Gender balance \\
\hline \multicolumn{4}{|l|}{ Pacific } \\
\hline 2020 & Kiribati & $\begin{array}{l}\text { UNJP/KIR/002/UNJ: Enhancing Food Security, Nutrition and } \\
\text { Resilience to COVID-19 in Kiribati }\end{array}$ & $\begin{array}{l}\text { Capacity-building on } \\
\text { production and marketing }\end{array}$ \\
\hline 2017-2020 & $\begin{array}{l}\text { Federated States of } \\
\text { Micronesia/Marshall Islands/ } \\
\text { Nauru/Palau/Kiribati }\end{array}$ & $\begin{array}{l}\text { TCP/SAP/3603: Aquaculture Business Investment Planning and } \\
\text { Development to Increase Resilience and Improve Food Security. } \\
\text { TCP/KIR/3602/C2: In-depth Aquaculture Risk Assessment and } \\
\text { Business Investment Planning }\end{array}$ & $\begin{array}{l}\text { Sector development; } \\
\text { investment planning }\end{array}$ \\
\hline 2016-2017 & Fiji & $\begin{array}{l}\text { OSRO/FIJ/602/BEL: Emergency Support to Re-establish } \\
\text { Agricultural, Fisheries and Aquatic Plant Production Post- } \\
\text { Tropical Cyclone Winston (Fiji) }\end{array}$ & Post-disaster recovery \\
\hline 2004 & Marshall Islands & $\begin{array}{l}\text { TCP/MAS/2801 or TCP/MAS/2902: Seaweed Cultivation in the } \\
\text { Marshall Islands }\end{array}$ & $\begin{array}{l}\text { Capacity-building on } \\
\text { production }\end{array}$ \\
\hline
\end{tabular}


Table 11: Examples of recent FAO publications on algae

\begin{tabular}{|c|c|c|}
\hline Year of publication & Title & Notes \\
\hline Forthcoming & $\begin{array}{l}\text { Occurrence and regulation of food safety hazards in seaweed and } \\
\text { aquatic plants: current status and future perspectives }\end{array}$ & Expected to be published in 2021 . \\
\hline Forthcoming & Genetic resources for farmed seaweeds & Draft report available at www.fao.org/3/CA3065EN/ca3065en.pdf \\
\hline 2021 & $\begin{array}{l}\text { Seaweeds and microalgae: an overview for unlocking their } \\
\text { potential in global aquaculture development }\end{array}$ & $\begin{array}{l}\text { FAO Fisheries and Aquaculture Circular No. } 1229 \text { (i.e. the current } \\
\text { document). }\end{array}$ \\
\hline 2021 & $\begin{array}{l}\text { Global seaweeds and microalgae production, } \\
\text { 1950-2019 }\end{array}$ & $\begin{array}{l}\text { World Aquaculture Performance Indicators (WAPI) factsheet. } \\
\text { www.fao.org/3/cb4579en/cb4579en.pdf }\end{array}$ \\
\hline 2021 & Seaweed revolution: where is the next milestone? & WAPI policy brief. www.fao.org/3/cb4850en/cb4850en.pdf\#page $=13$ \\
\hline 2020 & $\begin{array}{l}\text { Sargassum uses guide: a resource for Caribbean researchers, } \\
\text { entrepreneurs and policy makers }\end{array}$ & $\begin{array}{l}\text { CERMES Technical Report No. } 97 \text {. } \\
\text { www.cavehill.uwi.edu/cermes/projects/sargassum/docs/desrochers_et_al_ } \\
\text { 2020_sargassum_uses_guide_advance.aspx }\end{array}$ \\
\hline 2020 & $\begin{array}{l}\text { Understanding diseases and control in seaweed farming in } \\
\text { Zanzibar }\end{array}$ & $\begin{array}{l}\text { FAO Fisheries and Aquaculture Technical Paper No. } 662 . \\
\text { www.fao.org/3/ca9004en/CA9004EN.pdf }\end{array}$ \\
\hline 2018 & The global status of seaweed production, trade and utilization & $\begin{array}{l}\text { FAO Globefish Research Programme, Vol. } 124 . \\
\text { www.fao.org/3/CA1121EN/ca1121en.pdf }\end{array}$ \\
\hline 2013 & $\begin{array}{l}\text { Social and economic dimensions of carrageenan seaweed } \\
\text { farming }\end{array}$ & $\begin{array}{l}\text { FAO Fisheries and Aquaculture Technical Paper No. } 580 . \\
\text { www.fao.org/3/a-i3344e.pdf }\end{array}$ \\
\hline 2013 & Seaweed for a better life & RFLP Report. www.fao.org/3/a-ar486e.pdf \\
\hline 2012 & Spirulina: a livelihood and a business venture & Report SF/2011/16. SmartFish. www.fao.org/3/az386e/az386e.pdf \\
\hline 2008 & $\begin{array}{l}\text { A review on culture, production and use of spirulina as food for } \\
\text { humans and feeds for domestic animals and fish }\end{array}$ & $\begin{array}{l}\text { FAO Fisheries and Aquaculture Circular No. } 1034 . \\
\text { www.fao.org/3/i0424e/i0424e00.pdf }\end{array}$ \\
\hline 2003 & A guide to the seaweed industry & $\begin{array}{l}\text { FAO Fisheries Technical Paper No. } 441 \text {. } \\
\text { www.fao.org/tempref/docrep/fao/006/y4765e/y4765e00.pdf }\end{array}$ \\
\hline
\end{tabular}




\section{REFERENCES}

Ahern, M., Thilsted, S.H. \& Oenema, S. 2021. The role of aquatic foods in sustainable healthy diets. Discussion paper. UN Nutrition. 64 pp. (also available at www.unnutrition.org/wp-content/uploads/FINAL-UN-Nutrition-Aquatic-foodsPaper_EN_.pdf).

Ambati, R.R., Phang, S.M., Ravi, S. \& Aswathanarayana, R.G. 2014. Astaxanthin: sources, extraction, stability, biological activities and its commercial applications-a review. Marine drugs, 12(1): 128-152. https://doi.org/10.3390/md12010128

Anderson, D.M., Cembella, A.D. \& Hallegraeff, G.M. 2012. Progress in understanding harmful algal blooms: paradigm shifts and new technologies for research, monitoring, and management. Annual Review of Marine Science, 4: 143-76. doi: 10.1146/annurev-marine-120308-081121. PMID: 22457972; PMCID: PMC5373096

ANSES (French Agency for Food, Environmental and Occupational Health \& Safety). 2020. Opinion of the French Agency for Food, Environmental and Occupational Health \& Safety on "maximum cadmium levels for seaweed intended for human consumption". 21 July 2020. 57 pp. (also available at www.anses.fr/en/system/files/ERCA2017SA0070EN.pdf).

Armenta, R.E. \& Valentine, M.C. 2013. Single-cell oils as a source of omega-3 fatty acids: an overview of recent advances. Journal of the American Oil Chemists' Society, 90: 167-182. https://doi.org/10.1007/s1 1746-012-2154-3

Ask, E. 2001. Creating a sustainable commercial Eucheuma cultivation industry: the importance and necessity of the human factor. In A. Chapman, R. Anderson, V. Vreeland \& I. Davison, eds. 17th International Seaweed Symposium, pp. 13-18. Oxford University Press.

Bak, U.G., Gregersen, Ó. \& Infante, J. 2020. Technical challenges for offshore cultivation of kelp species: lessons learned and future directions. Botanica Marina, 63(4): 341-353. https://doi.org/10.1515/bot-2019-0005

Banach, J.L., Hoek-van den Hil, E.F. \& van der Fels-Klerx, H.J. 2020. Food safety hazards in the European seaweed chain. Comprehensive Reviews in Food Science and Food Safety, 19: 332-364. https://doi.org/10.1111/1541-4337.12523

Barbier, M., Charrier, B., Araujo, R., Holdt, S.L., Jacquemin, B. \& Rebours, C. 2019. PEGASUS - Phycomorph European Guidelines for a Sustainable Aquaculture of Seaweeds. M. Barbier \& B. Charrier, eds. COST Action FA1406 (2015-2019). Roscoff, France. https://doi.org/10.21411/2c3w-yc73

Barkia, I., Saari, N. \& Manning, S.R. 2019. Microalgae for high-value products towards human health and nutrition. Marine Drugs, 17(5): 304. doi: 10.3390/md17050304. PMID: 31137657 ; PMCID: PMC6562505.

Barrington, K., Chopin, T. \& Robinson, S. 2009. Integrated multi-trophic aquaculture (IMTA) in marine temperate waters. In D. Soto, ed. Integrated mariculture: a global review. FAO Fisheries and Aquaculture Technical Paper No. 529. Rome, FAO. pp. 7-46.

Bixler, H. \& Porse, H. 2011. A decade of change in the seaweed hydrocolloids industry. Journal of Applied Phycology, 23: 321-335.

Bjerregaard, R., Valderrama, D., Radulovich, R., Diana, J., Capron, M., Mckinnie, C.A., Cedric, M., Hopkins, K., Yarish, C., Goudey, C. \& Forster, J. 2016. Seaweed aquaculture for food security, income generation and environmental health in tropical developing countries. Washington, DC, World Bank Group. 16 pp. (also available at http://documents.worldbank.org/curated/en/947831469090666344/Seaweed-aquaculture-forfood-security-income-generation-and-environmental-health-in-Tropical-DevelopingCountries).

Bouga, M. \& Combet, E. 2015. Emergence of seaweed and seaweed-containing foods in the UK: focus on labeling, iodine content, toxicity and nutrition. Foods, 4(2): 240-253. doi: 10.3390/foods4020240. PMID: 28231201; PMCID: PMC5302319. 
Buschmann, A.H., Hernández-González, M.C., Aroca, G. \& Gutierrez, A. 2021. Seaweed farming in Chile: a review. Global Aquaculture Advocate. www.aquaculturealliance.org/advocate/seaweed-farming-in-chile-areview/?savePDF=cf4883b0b60c43472a1e3165efd56633\&article=seaweed-farming-in-chilea-review

Byeon, S.Y., Oh, H.J. \& Kim, S. et al. 2019. The origin and population genetic structure of the 'golden tide' seaweeds, Sargassum horneri, in Korean waters. Scientific Reports, 9: 7757. https://doi.org/10.1038/s41598-019-44170-x

Cai, J., Hishamunda, N. \& Ridler, N. 2013. Social and economic dimensions of carrageenan seaweed farming: a global synthesis. In D. Valderrama, J. Cai, N. Hishamunda \& N. Ridler, eds. Social and economic dimensions of carrageenan seaweed farming, pp. 5-59. FAO Fisheries and Aquaculture Technical Paper No. 580. Rome, FAO. 204 pp. (also available at www.fao.org/3/i3344e/i3344e.pdf).

Cai, J., Lovatelli, S., Stankus, A. \& Zhou, X. 2021. Seaweed revolution: where is the next milestone? FAO Aquaculture Newsletter, 63. pp. 13-16. www.fao.org $/ 3 / \mathrm{cb} 4850 \mathrm{en} / \mathrm{cb} 4850 \mathrm{en} . \mathrm{pdf} \#$ page $=13$

Campbell, I., Macleod, A., Sahlmann, C., Neves, L., Funderud, J., Øverland, M., Hughes, A.D. \& Stanley, M. 2019a. The environmental risks associated with the development of seaweed farming in Europe - prioritizing key knowledge gaps. Frontiers in Marine Science, 6, [107]. https://doi.org/10.3389/fmars.2019.00107

Campbell, I., Kambey, C., Mateo, J., Rusekwa, S., Hurtado, A., Msuya, F., Stentiford, G.D. \& Cottier-Cook, E. 2019b. Biosecurity policy and legislation for the global seaweed aquaculture industry. Journal of Applied Phycology. doi:10.1007/s10811-019-02010-5

Chen, H., Zhou, D., Luo, G., Zhang, S. \& Chen, J. 2015. Macroalgae for biofuels production: progress and perspectives. Renewable and Sustainable Energy Reviews, 47: 427-437. https://doi.org/10.1016/j.rser.2015.03.086

Cherry, P., Yadav, S., Strain, C.R., et al. 2019. Prebiotics from seaweeds: an ocean of opportunity? Marine Drugs, 17(6): 327. doi:10.3390/md17060327

Chia, W.Y., Ying Tang, D.Y., Khoo, K.S., Kay Lup, A.N. \& Chew, K.W. 2020. Nature's fight against plastic pollution: algae for plastic biodegradation and bioplastics production. Environmental Science and Ecotechnology, 4: 100065.

https://doi.org/10.1016/j.ese.2020.100065

Chua, E.T., Shekh, A.Y., Eltanahy, E., Thomas-Hall, S.R. \& Schenk, P.M. 2020. Effective harvesting of Nannochloropsis microalgae using mushroom chitosan: a pilot-scale study. Frontiers in Bioengineering and Biotechnology, 8. (also available at www.frontiersin.org/article/10.3389/fbioe.2020.00771).

Craigie, J.S., Cornish, M.L. \& Deveau, L.E. 2019. Commercialization of Irish moss aquaculture: the Canadian experience. Botanica Marina, 62(5): 411-432. (also available at https://doi.org/10.1515/bot-2019-0017).

Davis, M. 2021. The Year Bali Tourism Stopped. ABC News (Australian Broadcasting Corporation), 8 March 2021. (also available at www.abc.net.au/news/2021-03-09/bali-returnof-seaweed-farming-ceningan-lembongan-penida-covid/13202170).

Desrochers, A., Cox, S-A., Oxenford, H.A. \& van Tussenbroek, B. 2020. Sargassum uses guide: a resource for Caribbean researchers, entrepreneurs and policy makers. Report funded by and prepared for the Climate Change Adaptation in the Eastern Caribbean Fisheries Sector (CC4FISH) Project of the Food and Agriculture Organization (FAO). Centre for Resource Management and Environmental Studies (CERMES), University of the West Indies, Cave Hill Campus. Bridgetown, Barbados. CERMES Technical Report No. 97. 172 pp.

Devault, D., Ménez, F., Péné-Annette, A. \& Lopez, P.J. 2020. Eco3Sar: ecologie, ecotoxicologie et economie des sargasses. Agence de la Transition Ecologique (ADEME). 126 pp.

Diatin, I., Effendi, I. \& Taufik, M.A. 2020. The production function and profitability analysis of Gracilaria sp. seaweed polyculture with milkfish (Chanos chanos) and black tiger shrimp (Penaeus monodon). Biodiversitas, 21: 4747-4754. doi: 10.13057/biodiv/d211039

Dixon, C. \& Wilken, L.R. 2018. Green microalgae biomolecule separations and recovery. Bioresources and Bioprocessing, 5(14). https://doi.org/10.1186/s40643-018-0199-3 
Duarte, C.M., Agusti, S., Barbier, E. et al. 2020. Rebuilding marine life. Nature, 580, 39-51. (also available at https://doi.org/10.1038/s41586-020-2146-7).

Duarte, C.M., Wu, J., Xiao, X., Bruhn, A. \& Krause-Jensen, D. 2017. Can seaweed farming play a role in climate change mitigation and adaptation? Frontier in Marine Science, 4, 100.

Eamer, C. 2016. Seaweed economics 101: boom and bust in the North Atlantic. Hakai Magazine, 5 January 2016. www.hakaimagazine.com/features/seaweed-economics-101-boom-and-bustnorth-atlantic

EFSA NDA Panel (Panel on Nutrition, Novel Foods and Food Allergens), Turck, D., Castenmiller, J., De Henauw, S., Hirsch-Ernst, K.I., Kearney, J., Maciuk, A., Mangelsdorf, I., McArdle, H.J., Naska, A., Pelaez, C., Pentieva, K., Siani, A., Thies, F., Tsabouri, S., Vinceti, M., Cubadda, F., Engel, K.H., Frenzel, T., Heinonen, M., Marchelli, R., Neuhauser-Berthold, M., Poulsen, M., Sanz, Y., Schlatter, J.R., van Loveren, H., Ferreira, L. \& Knutsen, H.K. 2020. Scientific opinion on the safety of Schizochytrium sp. oil as a novel food pursuant to Regulation (EU) 2015/2283. EFSA Journal, 18(10): 6242. 24 pp. https://doi.org/10.2903/j.efsa.2020.6242

El Boukhari, M., Barakate, M., Bouhia, Y. \& Lyamlouli, K. 2020. Trends in seaweed extract based biostimulants: manufacturing process and beneficial effect on soil-plant systems. Plants, 9(3): 359. https://doi.org/10.3390/plants9030359

Fang, J., Zhang, J., Xiao, T., Huang, D. \& Liu, S. 2015. Introduction: integrated multi-trophic aquaculture (IMTA) in Sanggou Bay, China. Aquaculture Environment Interactions, 8: $201-$ 206. [Cited 15 April 2021]. www.jstor.org/stable/24864980

FAO. 2018. The global status of seaweed production, trade and utilization. Globefish Research Programme, Volume 124. Rome. 120 pp. Licence: CC BY-NC-SA 3.0 IGO.

FAO. 2019. The State of the World's Aquatic Genetic Resources for Food and Agriculture. FAO Commission on Genetic Resources for Food and Agriculture assessments. Rome.

FAO. 2020a. The State of World Fisheries and Aquaculture 2020. Sustainability in action. Rome. https://doi.org/10.4060/ca9229en

FAO. 2020b. Report of the Second Multi-Stakeholder Consultation on the Progressive Management Pathway for Improving Aquaculture Biosecurity (PMP/AB). Paris, France, 29-31 January 2019. FAO Fisheries and Aquaculture Report No. 1321. Rome. https://doi.org/10.4060/cb0745en

FAO. 2020c. Report of the Progressive Management Pathway for Improving Aquaculture Biosecurity (PMP/AB): First Technical Working Group Meeting, Rome, 20-22 March 2019. FAO Fisheries and Aquaculture Report No. 1322. Rome. https://doi.org/10.4060/cb0582en

FAO. 2020d. Progress Towards Development of the Progressive Management Pathway for Improving Aquaculture Biosecurity (PMP/AB): Highlights of 2019 Activities. FAO Fisheries and Aquaculture Circular No. 1211. Rome. https://doi.org/10.4060/cb0560en

FAO. 2021a. Top 10 species groups in global aquaculture 2019. World Aquaculture Performance Indicators (WAPI) factsheet. $4 \mathrm{pp}$. www.fao.org/3/cb5186en/cb5186en.pdf

FAO. 2021b. Top 10 species groups in global, regional and national aquaculture 2019. World Aquaculture Performance Indicators (WAPI) factsheet. $325 \mathrm{pp}$. (also available at www.fao.org/3/cb5012en/cb5012en.pdf).

FAO. 2021c. Fishery and Aquaculture Statistics. Global Production Statistics 1950-2019. In: FAO Fisheries Division [online]. FishStaJ - Software for Fishery and Aquaculture Statistical Time Series. www.fao.org/fishery/statistics/software/fishstatj/en

FAO. 2021d. Global seaweed and microalgae production, 1950-2019. World Aquaculture Performance Indicators (WAPI) factsheet. $172 \mathrm{pp}$. (also available at www.fao.org/3/cb4579en/cb4579en.pdf).

FAO. Forthcoming. Genetic resources for farmed freshwater macrophytes: a review. Thematic background study for the Global Conference on Aquaculture Millennium +20 (22-27 September 2021). https://aquaculture2020.org

Fernández, P.A., Leal, P.P. \& Henríquez, L.A. 2019. Co-culture in marine farms: macroalgae can act as chemical refuge for shell-forming molluscs under an ocean acidification scenario. Phycologia, 58(5): 542-551. doi: 10.1080/00318884.2019.1628576 
Gadberry, B.A., Colt, J., Maynard, D., Boratyn, D.C., Webb, K., Johnson, R.B., Saunders, G.W. \& Boyer, R.H. 2019. Intensive land-based production of red and green macroalgae for human consumption in the Pacific Northwest: an evaluation of seasonal growth, yield, nutritional composition, and contaminant levels. Algae, 33: 109-125.

Gladyshev, M.I. \& Gubelit, Y.I. 2019. Green tides: new consequences of the eutrophication of natural waters (invited review). Contemporary Problems of Ecology, 12: 109-125.

Godínez-Ortega, J.L., Cuatlán-Cortés, J.V., López-Bautista, J.M. \& van Tussenbroek, B.I. 2021. A Natural history of floating Sargassum species (Sargasso) from Mexico [Online]. IntechOpen. doi: 10.5772/intechopen.97230

Gómez-Zorita, S., González-Arceo, M., Trepiana, J., Eseberri, I., Fernández-Quintela, A., Milton-Laskibar, I., Aguirre, L., González, M. \& Portillo, M.P. 2020. Anti-obesity effects of macroalgae. Nutrients, 12(8): 2378. doi: 10.3390/nu12082378. PMID: 32784488; PMCID: PMC7469045.

Granada, L., Lopes, S., Novais, S.C. \& Lemos, M.F.L. 2018. Modelling integrated multitrophic aquaculture: optimizing a three trophic level system. Aquaculture, 495: 90-97.

Grebe, G.S., Byron, C.J., Gelais, A.S., Kotowicz, D.M. \& Olson, T.K. 2019. An ecosystem approach to kelp aquaculture in the Americas and Europe. Aquaculture Reports, 15: 100215. doi: 10.1016/j.aqrep.2019.100215

Habib, M.A.B., Parvin, M., Huntington, T.C. \& Hasan, M.R. 2008. A review on culture, production and use of spirulina as food for humans and feeds for domestic animals and fish. FAO Fisheries and Aquaculture Circular No. 1034. Rome, FAO. 33 pp. (also available at www.fao.org/3/i0424e/i0424e00.pdf).

Henley, W., Litaker, R., Novoveská, L., Duke, C., Quemada, H. \& Sayre, R. 2012. Initial risk assessment of genetically modified (GM) microalgae for commodity-scale biofuel cultivation. Algal Research, 2(1): 66-77.

Hasselström, L., Visch, W., Gröndahl, F., Nylund, G.M. \& Pavia, H. 2018. The impact of seaweed cultivation on ecosystem services - a case study from the west coast of Sweden. Marine Pollution Bulletin, 133: 53-64.

Hill, R.T. 2017. Genetic resources for microorganisms of current and potential use in aquaculture. Thematic background study No. 2. (also available at www.fao.org/cofi/46054-0758de68f3799088c2c9633d04d81a313.pdf).

Hoegh-Guldberg, O. et al. 2019. The ocean as a solution to climate change: five opportunities for action. Report. Washington, DC, World Resources Institute. www.oceanpanel.org/climate

Holdt, S.L. \& Kraan, S. 2011. Bioactive compounds in seaweed: functional food applications and legislation. Journal of Applied Phycology, 23: 543-597.

Hu, C., Li, D., Chen, C., Ge, J., Muller-Karger, F.E., Liu, J., Yu, F. \& He, M.X. 2010. On the recurrent Ulva prolifera blooms in the Yellow Sea and East China Sea. Journal of Geophysical Research: Ocean, 115: C05017. https://doi.org/10.1029/2009JC005561

Hu, Z.M., Shan, T.F., Zhang, J., Zhang, Q.S., Critchley, A.T., Choi, H.G. et al. 2021. Kelp aquaculture in China: a retrospective and future prospects. Reviews in Aquaculture, 13, doi: $10.1111 /$ raq. 12524

Hughes, A.D. \& Black, K.D. 2016. Going beyond the search for solutions: understanding tradeoffs in European integrated multi-trophic aquaculture development. Aquaculture Environment Interactions, 8: 191-199. https://doi.org/10.3354/aei00174

Hurtado, A.Q. 2013. Social and economic dimensions of carrageenan seaweed farming in the Philippines. In D. Valderrama, J. Cai, N. Hishamunda \& N. Ridler, eds. Social and economic dimensions of carrageenan seaweed farming, pp. 91-113. Fisheries and Aquaculture Technical Paper No. 580. Rome, FAO. 204 pp.

Hurtado, A.Q., Montano, M.N.E. \& Martinez-Goss, M.R. 2013. Commercial production of carrageenophytes in the Philippines: ensuring long-term sustainability for the industry. Journal of Applied Phycology, 25: 733-742.

Hurtado, A.Q., Neish, I.C. \& Critchley, A.T. 2019. Phyconomy: the extensive cultivation of seaweeds, their sustainability and economic value, with particular reference to important lessons to be learned and transferred from the practice of eucheumatoid farming. Phycologia, 58(5): 472-483. https://doi.org/10.1080/00318884.2019.1625632 
Hwang, E.K., Ha, D.S. \& Park, C.S. 2017. Strain selection and initiation timing influence the cultivation period of Saccharina japonica and their impact on the abalone feed industry in Korea. Journal of Applied Phycology, 29: 2297-2305.

https://doi.org/10.1007/s10811-017-1179-2

Hwang, E.K., Yotsukura, N., Pang, S.J., Su, L. \& Shan, T.F. 2019. Seaweed breeding programs and progress in eastern Asian countries. Phycologia, 58(5): 484-495.

doi: 10.1080/00318884.2019.1639436

IIMSAM (The Autonomous Intergovernmental Institution for the Use of Micro-algae Spirulina Against Malnutrition). 2021. Progress report on the "Free Spirulina distribution programme to fight malnutrition".

https://sustainabledevelopment.un.org/partnership/?p=13211\#: :text=local\%20Health\%20Mi nistry.-

,the $\% 20$ Autonomous $\% 20$ Intergovernmental\%20Institution $\% 20$ for $\% 20$ the $\% 20$ use $\% 20$ of $\% 20$ Micro\%2Dalgae,Nations\%20Economic\%20and\%20Social\%20Council.

Ismail, M.M. 2019. Review on seaweed as supplement fish feed. Oceanography \& Fisheries Open Access Journal, 11(2): 555808. doi: 10.19080/OFOAJ.2019.11.555808

JECFA Secretariats. 2021. Matters of interest arising from FAO and WHO including JECFA. Prepared by the Joint FAO/WHO JECFA Secretariats for the Joint FAO/WHO Food Standards Programme (14th Session [virtual], 3-7 and 13 May 2021). CODEX Committee on Contaminants in Foods, Codex Alimentarius Commission. (also available at www.fao.org/fao-who-codexalimentarius/shproxy/en/?lnk=1\&url=https $\% 253 \mathrm{~A} \% 252 \mathrm{~F} \% 252 \mathrm{~F}$ workspace.fao.org\%252Fsites $\% 252 \mathrm{Fcodex}$ \%252FMeetings\%252FCX-735-14\%252FWDs-2021\%252Fcf14 03e.pdf).

Jensen, G.S., Ginsberg, D.I. \& Drapeau, C. 2001. Blue-green algae as an immuno-enhancer and biomodulator. Journal of the American Nutraceutical Association, 3:24-30.

Jia, T., Zhang, X. \& Dong, R. 2019. Long-term spatial and temporal monitoring of cyanobacteria blooms using MODIS on Google Earth Engine: a case study in Taihu Lake. Remote Sensing, 11: 2269. https://doi.org/10.3390/rs11192269

Jones, N. 2021. Why the market for 'blue carbon' credits may be poised to take off. Yale Environment 360. The Yale School of the Environment. https://e360.yale.edu/features/whythe-market-for-blue-carbon-credits-may-be-poised-to-take-off

Kenicer, G., Bridgewater, S. \& Milliken, W. 2000. The ebb and flow of Scottish seaweed use Botanical Journal of Scotland, 52: 119-148.

Khan, M.I., Shin, J.H. \& Kim, J.D. 2018. The promising future of microalgae: current status, challenges, and optimization of a sustainable and renewable industry for biofuels, feed, and other products. Microbial Cell Factories, 17: 36. https://doi.org/10.1186/s12934-018-0879-x

Kim, G.H., Moon, K.-H., Kim, J.-Y., Shim, J. \& Klochkova, T.A. 2014. A revaluation of algal diseases in Korean Pyropia (Porphyra) sea farms and their economic impact. Algae, 29: 249-265.

Kleitou, P., Kletou, D. \& David, J. 2018. Is Europe ready for integrated multitrophic aquaculture? A survey on the perspectives of European farmers and scientists with IMTA experience. Aquaculture, 490: 136-148. doi: 10.1016/j.aquaculture.2018.02.035

Krause-Jensen, D. \& Duarte, C. 2016. Substantial role of macroalgae in marine carbon sequestration. Nature Geoscience, 9: 737-742. https://doi.org/10.1038/ngeo2790

Krishnan, M. \& Narayanakumar, R. 2013. Social and economic dimensions of carrageenan seaweed farming in India. In D. Valderrama, J. Cai, N. Hishamunda \& N. Ridler, eds. Social and economic dimensions of carrageenan seaweed farming, pp. 163-184. Fisheries and Aquaculture Technical Paper No. 580. Rome, FAO. 204 pp.

Kumar, G., Shekh, A., Jakhu, S., Sharma, Y., Kapoor, R. \& Sharma, T.R. 2020. Bioengineering of microalgae: recent advances, perspectives, and regulatory challenges for industrial application. Frontiers in Bioengineering and Biotechnology, 8: 914. doi:10.3389/fbioe.2020.00914

Lähteenmäki-Uutela, A., Rahikainen, M., Camarena-Gómez, M.T. et al. 2021. European Union legislation on macroalgae products. Aquaculture International, 29: 487-509.

https://doi.org/10.1007/s10499-020-00633-x 
Lam, M.K. \& Lee, K.T. 2012. Microalgae biofuels: a critical review of issues, problems and the way forward. Biotechnology Advances, 30: 673-690.

Lance, Q., Mu, Y., Zhao, Z., Lam, V.W. \& Sumaila, U.R. 2017. Economic challenges to the generalization of integrated multi-trophic aquaculture: an empirical comparative study on kelp monoculture and kelp-mollusk polyculture in Weihai, China. Aquaculture, 471: 130-139.

Lange, L., Bak, U.G., Hansen, S.C.B., Gregersen, O., Harmsen, P., Karlsson, E.N., Meyer, A., Mikkelsen, M.D., van Den Broek, L. \& Hreggviðsson, G.Ó. 2020. Chapter 1 - Opportunities for seaweed biorefinery. In M.D. Torres, S. Kraan \& H. Dominguez, ed. Sustainable seaweed technologies - cultivation, biorefinery, and applications, pp. 3-31. Elsevier.

Largo, D.B., Msuya, F.E. \& Menezes, A. 2020. Understanding diseases and control in seaweed farming in Zanzibar. FAO Fisheries and Aquaculture Technical Paper No. 662. Rome, FAO. https://doi.org/10.4060/ca9004en

Lauzon-Guay, J.S., Ugarte, R.A., Morse, B.L. \& Robertson, C.A. 2021. Biomass and height of Ascophyllum nodosum after two decades of continuous commercial harvesting in eastern Canada. Journal of Applied Phycology, 33: 1695-1708. https://doi.org/10.1007/s10811-021-02427-x

Lavens, P. \& Sorgeloos, P., eds. 1996. Manual on the production and use of live food for aquaculture. FAO Fisheries Technical Paper No. 361. Rome, FAO. 295 pp. (also available at www.fao.org/3/w3732e/w3732e.pdf).

Leal, M.C., Munro, M.H., Blunt, J.W., Puga, J., Jesus, B., Calado, R., Rosa, R. \& Madeira, C. 2013. Biogeography and biodiscovery hotspots of macroalgal marine natural products. Natural Product Reports, 30(11): 1380-90. doi: 10.1039/c3np70057g. PMID: 23982267. https://pubmed.ncbi.nlm.nih.gov/23982267

Leal, M.C., Anaya-Rojas, J.M., Munro, M.H.G., Blunt, J.W., Melian, C.J., Calado, R. \& Lürig, M.D. 2020. Fifty years of capacity building in the search for new marine natural products. Proceedings of the National Academy of Sciences of the United States of America, 117(39): 24165-24172. doi: 10.1073/pnas.2007610117. PMID: 32929019; PMCID: PMC7533840. https://pubmed.ncbi.nlm.nih.gov/32929019

Lehahn, Y., Ingle, K.N. \& Golberg, A. 2016. Global potential of offshore and shallow waters macroalgal biorefineries to provide for food, chemicals and energy: feasibility and sustainability. Algal Research, 17: 150-160. 10.1016/j.algal.2016.03.031

Lentisco, A. \& Needham, S. 2013. Seaweed for a better life. Regional Fisheries Livelihoods Programme for South and Southeast Asia (RFLP) report. (also available at www.fao.org/fileadmin/templates/rap/files/NRE/Fisheries/case_study_seaweed_for_a_better_ life.pdf).

Liu, F., Liang, Z., Zhang, P., Wang, W., Sun, X., Wang, F. \& Yuan, Y. 2019. Preliminary discussion on the development of Saccharina japonica offshore aquaculture in China [J]. Progress in Fishery Sciences, 40(1): 161-166. doi: 10.19663/j.issn2095-9869.20180726002. (in Chinese)

Loureiro, R., Gachon, C.M. \& Rebours, C. 2015. Seaweed cultivation: potential and challenges of crop domestication at an unprecedented pace. New Phytologist, 206(2): 489-492. https://doi.org/10.1111/nph.13278

Mantri, V.A., Shah, Y. \& Thiruppathi, S. 2020. Feasibility of farming the agarose-yielding red alga Gracilariadura using tube-net cultivation in the open sea along the Gujarat coast of NW India. Applied Phycology, 1(1): 12-19. doi: 10.1080/26388081.2019.1648181

Mao, Y., Lin, F., Fang, J., Fang, J., Li, J. \& Du, M. 2019. Bivalve production in China. In A. Smaal, J. Ferreira, J. Grant, J. Petersen \& Ø. Strand., eds. Goods and Services of Marine Bivalves. Springer, Cham. https://doi.org/10.1007/978-3-319-96776-9_4

McHugh, D.J. 2003. A guide to the seaweed industry. Fisheries Technical Paper No. 441. Rome, FAO. 105 pp.

Mendes, A., Reis, A., Vasconcelos, R. et al. 2009. Crypthecodinium cohnii with emphasis on DHA production: a review. Journal of Applied Phycology, 21: 199-214.

https://doi.org/10.1007/s10811-008-9351-3 
Milinovic, J., Mata, P., Diniz, M. \& Noronha, J.P. 2021.Umami taste in edible seaweeds: The current comprehension and perception. International Journal of Gastronomy and Food Science, 23, 100301 .

Monagail, M.M., Cornish, L., Morrison, L., Araújo, R. \& Critchley, A.T. 2017. Sustainable harvesting of wild seaweed resources. European Journal of Phycology, 52(4): 371-390. doi: 10.1080/09670262.2017.1365273

Mouritsen, O.G. 2013. Seaweeds: edible, available and sustainable. Chicago, University of Chicago Press. 272 pp.

Muraoka, D. 2004. Seaweed resources as a source of carbon fixation. Bulletin of Fisheries Research Agency, Supplement No. 1: 59-63.

Msuya, F.E. 2013. Social and economic dimensions of carrageenan seaweed farming in the United Republic of Tanzania. In D. Valderrama, J. Cai, N. Hishamunda \& N. Ridler, eds. Social and economic dimensions of carrageenan seaweed farming, pp. 115-146. Fisheries and Aquaculture Technical Paper No. 580. Rome, FAO. 204 pp.

Nabti, E., Jha, B. \& Hartmann, A. 2017. Impact of seaweeds on agricultural crop production as biofertilizer. International Journal of Environmental Science and Technology, 14: 1119-1134. https://doi.org/10.1007/s13762-016-1202-1

Naidoo, K., Maneveldt, G., Ruck K. \& Bolton, J.J. 2006. A comparison of various seaweed-based diets and formulated feed on growth rate of abalone in a land-based aquaculture system. In R. Anderson, J. Brodie, E. Onsøyen \& A.T. Critchley, eds. Eighteenth International Seaweed Symposium. Developments in Applied Phycology, Vol 1. Dordrecht, Springer. https://doi.org/10.1007/978-1-4020-5670-3_26

NOAA (National Oceanic and Atomospheric Administration). 2021. What is a red tide? Ocean facts. National Ocean Service. United States of America, NOAA. https://oceanservice.noaa.gov/facts/redtide.html

Onomu, A.J., Vine, N.G., Cyrus, M.D., Macey, B.M. \& Bolton, J.J. 2020. The effect of fresh seaweed and a formulated diet supplemented with seaweed on the growth and gonad quality of the collector sea urchin, Tripneustes gratilla, under farm conditions. Aquaculture Research, 51: 4087-4102. https://doi.org/10.1111/are.14752

Parodi, A., Leip, A., De Boer, I.J.M. et al. 2018. The potential of future foods for sustainable and healthy diets. Nature Sustainability, 1: 782-789. https://doi.org/10.1038/s41893-018-0189-7

Pereira, L. 2016. Edible seaweeds of the world. Boca Raton, CRC Press. 463 pp. https://doi.org/10.1201/b19970

Pérez Lloréns, J.L., Hernández, I., Vergara, J.J., Brun, F.G. \& León, Á. 2018. Those curious and delicious seaweeds: a fascinating voyage from biology to gastronomy. Cádiz, Spain, UCA Press. ISBN 978-84-9828-666-3

Piccolo, A. 2012. Spirulina: a livelihood and a business venture. Report SF/2011/16. SmartFish. www.fao.org/3/az386e/az386e.pdf

Pirian, K., Moein, S., Sohrabipour, J. et al. 2017. Antidiabetic and antioxidant activities of brown and red macroalgae from the Persian Gulf. Journal of Applied Phycology, 29: 3151-3159. https://doi.org/10.1007/s10811-017-1152-0

Racine, P., Marley, A.C., Froehlich, H.E., Gaines, S.D., Ladner, I., MacAdam-Somer, I. \& Bradley, D. 2021. A case for seaweed aquaculture inclusion in U.S. nutrient pollution management. Marine Policy, 129. https://doi.org/10.1016/j.marpol.2021.104506

Ragaza, J.A., Hossain, M.S., Meiler, K.A., Velasquez, S.F. \& Kumar, V. 2020. A review on Spirulina: alternative media for cultivation and nutritive value as an aquafeed. Reviews in Aquaculture, 12: 2371-2395. https://doi.org/10.1111/raq.12439

Ranjan, R. 2021. Seaweed cultivation and value chain development in India. Presentation in the international webinar: Entrepreneurship Development on Seaweed Business by Cooperatives. www.ncdc.in/documents/whats-new/3116290121Seaweed-PPT 28012021.pdf

Reddy, C.R.K., Yokoya, N.S., Yong, W.T.L., Luhan, M.R.J. \& Hurtado, A.Q. 2017. Micropropagation of Kappaphycus and Eucheuma: trends and prospects. In A.Q. Hurtado, A.T. Critchley \& I.C. Neish, eds. Tropical seaweed farming trends, problems and opportunities, pp. 91-110. 
Rhatigan, P. 2009. Irish seaweed kitchen: the comprehensive guide to healthy everyday cooking with seaweeds. Holywood, Ireland, Booklink. 288 pp.

Roque, B.M., Venegas, M., Kinley, R.D., de Nys, R., Duarte, T.L., Yang, X. et al. 2021. Red seaweed (Asparagopsis taxiformis) supplementation reduces enteric methane by over 80 percent in beef steers. PLOS ONE, 16(3): e0247820.

https://doi.org/10.1371/journal.pone.0247820

Sanseverino, I., Conduto António, D., Pozzoli, L., Dobricic, S. \& Lettieri, T. 2016. Algal bloom and its economic impact. EUR 27905. Publications Office of the European Union, Luxembourg, ISBN 978-92-79-58101-4 [online], 978-92-79-74157-9 (ePub). doi:10.2788/660478 (online),10.2788/880134 (ePub), JRC101253.

Sato, Y., Nagoe, H., Ito, M., Konishi, T., Fujimura, H., Nishihara, G.N. \& Tanaka, A. 2021. Final yield of the brown alga Cladosiphon okamuranus (Chordariaceae, Phaeophyceae) may depend on nursery quality. Phycological Research. https://doi.org/10.1111/pre.12453

Shannon, E. \& Abu-Ghannam, N. 2019. Seaweeds as nutraceuticals for health and nutrition. Phycologia, 58(5): 563-577. doi: 10.1080/00318884.2019.1640533

Smith, D. 2017. Invading fish threat to kelp forests. UNSW Magazine. Summer 2016/17. UNSW Sydney (the University of New South Wales). https://newsroom.unsw.edu.au/news/sciencetech/invading-fish-threat-kelp-forests

Soto, D., ed. 2009. Integrated mariculture: a global review. FAO Fisheries and Aquaculture Technical Paper No. 529. Rome, FAO. 194 pp. (also available at www.fao.org/3/i1092e/i1092e.pdf).

Spolaore, P., Joannis-Cassan, C., Duran, E. \& Isambert, A. 2006. Commercial applications of microalgae. Journal of Bioscience and Bioengineering, 101: 87-96.

Steen, H., Moy, F.E., Bodvin, T. \& Husa, V. 2016. Regrowth after kelp harvesting in NordTrøndelag, Norway. ICES Journal of Marine Science, 73: 2708-2720.

Su, L., Shan, T.F., Li, J., Pang, S.J., Leng, X.F., Zhang, Y. et al. 2020. Aquaculture of the hybrid cultivars of Saccharina japonica: removing the obstacle of sori production by photoperiodic control. Aquaculture, 519: 734917.

Suyo, J.G.B., Le Masson, V., Shaxson, L., Luhan, M.R.J. \& Hurtado, A.Q. 2020. A social network analysis of the Philippine seaweed farming industry: unravelling the web. Marine Policy, 118. https://doi.org/10.1016/j.marpol.2020.104007

Suyo, J.G.B., Le Masson, V., Shaxson, L., Luhan, M.R.J. \& Hurtado, A.Q. 2021. Bringing to light women's participation in the seaweed industry. Gender in Aquaculture and Fisheries Section [online].

www.genderaquafish.org/2021/02/27/bringing-to-light-womens-participation-in-the-seaweedindustry

Tacon, A. 1988. The nutrition and feeding of farmed fish and shrimp-a training manual: 3. Feeding methods. Report prepared for the FAO Trust Fund GCP/RLA/075/ITA Project Support to the Regional Aquaculture Activities for Latin America and the Caribbean. (also available at www.fao.org/3/AB467E/AB467E04.htm).

Theuerkauf, S.J., Morris, J.A. Jr, Waters, T.J., Wickliffe, L.C., Alleway, H.K. \& Jones, R.C. 2019. A global spatial analysis reveals where marine aquaculture can benefit nature and people. PLoS ONE, 14(10): e0222282. https://doi.org/10.1371/journal.pone.0222282

Tinellis, C., ed. 2014. Coastal chef: culinary art of seaweed and algae in the 21st century. Ulladulla, Australia, Harbour Publishing House. 258 pp.

Troell, M. 2009. Integrated marine and brackishwater aquaculture in tropical regions: research, implementation and prospects. In D. Soto, ed. Integrated mariculture: a global review, pp. 47131. FAO Fisheries and Aquaculture Technical Paper No. 529. Rome, FAO.

UCTV. 2019. Food, feed and climate change-emerging opportunities for shore based seaweed aquaculture [video]. The Jeffery B. Graham Perspectives on Ocean Science Lecture Series. University of California Television (UCTV). www.uctv.tv/shows/Food-Feed-and-ClimateChange-Emerging-Opportunities-for-Shore-Based-Seaweed-Aquaculture-34570

UNGA (The United Nations General Assembly). 2015. Draft Resolution on "The use of spirulina to combat hunger and malnutrition and help achieve sustainable development", proposed by Burundi, Cameroon, Dominican Republic, Nicaragua and Paraguay during the Sixtieth Session 
(2015) of the United Nations General Assembly (Second Committee, Agenda Item 52). https://digitallibrary.un.org/record/560424/files/A_C.2_60_L.14_Rev.1-EN.pdf

Valderrama, D., Cai, J., Hishamunda, N. \& Ridler, N., eds. 2013. Social and economic dimensions of carrageenan seaweed farming. Fisheries and Aquaculture Technical Paper No. 580. Rome, FAO. 204 pp. (also available at www.fao.org/3/i3344e/i3344e.pdf).

van den Burg, S.W.K., van Duijn, A.P., Bartelings, H., van Krimpen, M.M. \& Poelman, M. 2016. The economic feasibility of seaweed production in the North Sea. Aquaculture Economics \& Management, 20: 235-252.

van den Burg, S.W.K., Dagevos, H. \& Helmes, R.J.K. 2021. Towards sustainable European seaweed value chains: a triple P perspective. ICES Journal of Marine Science, 78(1): 443-450. https://doi.org/10.1093/icesjms/fsz183

van Iersel, S. \& Flammini, A. 2010. Algae-based biofuels: applications and co-products. FAO Environmental and Natural Resources Service Series No. 44. Rome, FAO. (also available at www.fao.org/3/i1704e/i1704e.pdf).

Wan-Loy, C. \& Siew-Moi, P. 2016. Marine algae as a potential source for anti-obesity agents. Marine Drugs, 14(12): 222. doi: 10.3390/md14120222. PMID: 27941599; PMCID: PMC5192459.

Wang, M., Hu, C., Barnes, B.B., Mitchum, G., Lapointe, B. \& Montoya, J.P. 2019. The great Atlantic Sargassum belt. Science, 365(6448): 83. doi: 10.1126/science.aaw7912.

Ward, G.M., Faisan, J.P., Cottier-Cook, E.J. et al. 2020. A review of reported seaweed diseases and pests in aquaculture in Asia. Journal of World Aquaculture Society, 51: 815-828. https://doi.org/10.1111/jwas.12649

Winckelmann, D., Bleeke, F., Thomas, B., Elle, C. \& Klöck, G. 2015. Open pond cultures of indigenous algae grown on non-arable land in an arid desert using wastewater. International Aquatic Research, 7, 221-233. https://doi.org/10.1007/s40071-015-0107-9

Xi, M. \& Dragsted, L.O. 2019. Biomarkers of seaweed intake. Genes \& Nutrition, 14 (24). https://doi.org/10.1186/s12263-019-0648-4

Xia, S., Yang, H., Li, Y., Liu, S., Zhou, Y. \& Zhang, L. 2012. Effects of different seaweed diets on growth, digestibility, and ammonia-nitrogen production of the sea cucumber Apostichopus japonicus (Selenka). Aquaculture, 338-341: 304-308.

Yong, W.T.L., Chin, G.J.W.L. \& Rodrigues, K.F. 2016. Genetic identification and mass propagation of economically important seaweeds. In N. Thajuddin \& D. Dhanasekaran, eds. Algae - organisms for imminent biotechnology, pp. 277-305. InTech. doi: 10.5772/62802.

Zhang, Y., He, P., Li, H. Li, G., Liu, J., Jiao, F., Zhang, J., Huo, Y., Shi, X., Su, R., Ye, N., Liu, D., Yu, R., Wang, Z., Zhou, M. \& Jiao, N. 2019a. Ulva prolifera green-tide outbreaks and their environmental impact in the Yellow Sea, China. National Science Review, 6(4): 825-838. https://doi.org/10.1093/nsr/nwz026

Zhang, J.H., Shi, J., Gao, S., Huo, Y., Cui, J., Shen, H., et al. 2019b. Annual patterns of macroalgal blooms in the Yellow Sea during 2007-2017. PLoS ONE, 14(1): e0210460. https://doi.org/10.1371/journal.pone.0210460

Zhang, J.Z., Tiller, C., Shen, J., Wang, C., Girouard, G.S., Dennis, D., Barrow, C.J., Miao, M. \& Ewart, H.S. 2007. Antidiabetic properties of polysaccharide- and polyphenolic-enriched fractions from the brown seaweed Ascophyllum nodosum. Canadian journal of physiology and pharmacology, 85(11): 1116-23. doi: 10.1139/Y07-105. PMID: 18066114.

Zhang, J.W. 2018. Seaweed industry in China. Unpublished manuscript. www.submarinernetwork.eu/images/grass/Seaweed_Industry_in_China.pdf 

ISBN 978-92-5-134710-2 ISSN 2070-6065

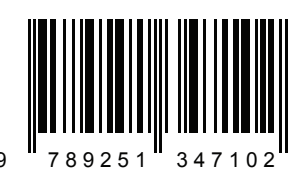
CB5670EN/1/07.2 